\title{
SOBRE OS LIMITES DA ARGUMENTAÇÃO JURÍDICA
}

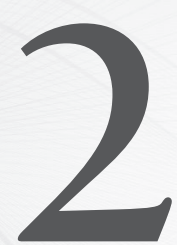

\section{A desconstrução do ativismo judicial fundado na ponderação de princípios e a reinvenção da legitimidade jurídica nos pensamentos de Jürgen Habermas e Chantal Mouffe}

On the limits of legal argumentation: the deconstruction of the judicial activism based on the balancing of principles and the reinvention of legal legitimacy in the thoughts of Jürgen Habermas and Chantal Mouffe

\section{Juliana Brina Corrêa lima de Carvalho}

Mestre em Direito Público pela UFMG (2009). Especialista em Controle da Administração Pública pela Universidade Gama Filho - UGF (2005). Especialista em Direitos Humanos, Teoria e Filosofia do Direito pela PUC-MG (2012 ). Extensão em Direito Constitucional e em Direitos Humanos em Harvard University. Pós-graduanda em Filosofia do Direito pela PUC-MG (2012). Assessora no TRE-MG.

Recebido em: 02.03.2012 Aprovado em: 29.03.2012

ÁreA do DiReITo: Fundamentos do Direito

Resumo: Este trabalho pretendeu, por meio de técnica de pesquisa teórica do tipo descritivo/ compreensivo e comparativo, e conforme processo de estudo interdisciplinar e procedimento
ABSTRACT: This paper intends to discuss the idea of legitimacy which is in the core of the understanding about the balancing principles method outlined in the wake of the judicial 
de análise de conteúdo, problematizar a ideia de legitimidade que é substrato do modelo de ponderação de princípios delineado no bojo do ativismo judicial assumido pela jurisprudência do Tribunal Constitucional Federal alemão (Bundesverfassungsgericht - BVG) e, no Brasil, pelos julgados do STF. Para tal, estudamos, inicialmente, o pensamento de Robert Alexy acerca da argumentação jurídica, por se constituir como uma das mais influentes interpretações da cultura constitucional alemã a tentar delinear uma metodologia para justificar racionalmente as dificuldades trazidas pela transição da jurisprudência do Bundesverfassungsgericht para o ativismo. Em seguida, procedemos à crítica da teoria da argumentação jurídica de Alexy por meio de duas vertentes: (a) as críticas endereçadas por Jürgen Habermas à teoria da argumentação jurídica, no que concerne à subordinação do direito à moral, bem como quanto à relativização do caráter deontológico dos princípios; e (b) a análise do modelo agonístico de democracia, proposto por Chantal Mouffe, aplicando-o à tentativa de desconstrução da pretensão de legitimidade do método ponderativo, a fim de criticar o modelo de racionalidade que the serve de substrato e o atrelamento deste ao modelo de legitimidade fundado na "representação argumentativa".

Palavras-chave: Legitimidade - Democracia agonística - Teoria discursiva - Teoria da Argumentação Jurídica - ativismo judicial. activism assumed by the German Federal Constitutional Court (Bundesverfassungsgericht - BVG) and, in Brazil, by the Supreme Court STF. Initially, we studied Robert Alexy's Teory of Legal Argumentantion as it constitutes one of the most influential interpretations of the German constitutional culture which tries to devise a methodology to rationally justify the difficulties brought about by the transition of the jurisprudence of the Bundesverfassungsgericht to activism. Then we proceeded to critically review Alexy's theory through two theories: (a) the criticisms addressed by Jürgen Habermas with respect to the Law subordination to Moral, as well as to the relativization of principles; and (b) the agonistic model of democracy proposed by Chantal Mouffe, so as to deconstruct the balancing method's claim to legitimacy, in order to criticize the model of rationality that serves as a substrate to the idea of legitimacy based on the "argumentative representation".

KeYwoRds: Legitimacy - Agonistic democracy - Discourse theory - Theory of Legal Argumentation - Judicial activism.

"We've got on to slippery ice where there is no friction and so in a certain sense the conditions are ideal, but also, just because of that, we are unable to walk: so we need friction. Back to the rough ground" (Wittgenstein, 1958, p. 46e).

SumÁRIO: 1. Introdução - 2. Ponderação como método de resolução de conflitos entre direitos fundamentais: racionalidade ou autoilusão?: 2.1 Estudo empírico-comparativo de dois casos da jurisprudência constitucional, alemã e da brasileira: 2.1.1 Caso Lüth - Tribunal Constitucional Federal alemão (Bundesverfassungsgericht - BVG); 2.1.2 Caso Ellwanger STF; 2.20 critério da proporcionalidade como método para justificação de intervenções em direitos fundamentais e solução de colisões - 3. Argumentação jurídica no pensamento de Robert Alexy: 3.1 A constatação de um problema: a interpretação jurídica como moldura no pensamento de Hans Kelsen; 3.2 Linhas centrais do pensamento de Robert Alexy; 3.3 
Ponderação, racionalidade e principios - 4. Sobre os limites da argumentação jurídica: desconstruindo a ponderação de princípios e o ativismo judicial: $4.1 \mathrm{~A}$ crítica habermasiana ao modelo de ponderação: 4.1.1 0 modelo discursivo de Jürgen Habermas; 4.1.2 A crítica habermasiana à Teoria da Argumentação Jurídica; 4.2 A crítica de Chantal Mouffe: 4.2.1 As investigações filosóficas de Wittgenstein; 4.2.2 0 modelo agonístico de Chantal Mouffe; 4.2.3 Aplicação do modelo agonístico de democracia aos problemas da legitimidade e da decidibilidade em caso de conflitos entre princípios - 5. Considerações finais - 6. Referências bibliográficas.

\section{INTRODUÇÃO}

A ponderação é o principal método utilizado por diversas cortes constitucionais, a fim de resolver conflitos entre direitos fundamentais. A Corte Europeia de Direitos Humanos, rotineiramente, pondera direitos humanos entre si e em relação a interesses públicos. Em seu âmbito, a proporcionalidade foi elevada ao status de princípio básico de interpretação.

Outrossim, no estudo da jurisprudência do Tribunal Constitucional Federal alemão (Bundesverfassungsgericht $-B V G$ ) e de suas repercussões nos julgados do STF, podemos constatar que as mencionadas Cortes, na esteira da adoção da ponderação de princípios, têm assumido uma postura de ativismo judicial, transformando-se, muitas vezes, em "fóruns" para o tratamento de problemas sociais e políticos. Ambas as Cortes têm demonstrado, ainda, uma tendência a compreender os direitos fundamentais como princípios objetivos inscritos no ordenamento, os quais possuiriam a natureza de mandamentos de otimização, de modo que, em conflito, precisariam ser ponderados.

A fim de justificar metodologicamente esse novo constitucionalismo e as decisões tomadas no bojo de tal ativismo, delineou-se, doutrinariamente, o modelo da ponderação de princípios, como instância da proporcionalidade em sentido estrito, no âmbito de aplicação do princípio da proporcionalidade. Este, por sua vez, é tomado, no contexto das decisões do BVG, como meta-princípio que guia a tomada de decisão em caso de colisões de princípios. A dogmática dos direitos fundamentais encontra-se, pois, em uma situação paradoxal, na medida em que deve elaborar discursos de interpretação e de aplicação do direito constitucional que não se deduzem diretamente do texto constitucional.

A relação entre Política e Direito, apesar de disciplinada constitucional e infraconstitucionalmente, não se esgota em tal disciplina, mas a transcende e a informa. Em geral, a doutrina jurídica entende que considerações políticas não devem contrariar disposições jurídicas em vigor, sob pena de ilegalidade ou inconstitucionalidade. Entretanto, por não serem capazes de regular, em 
sua totalidade, os casos sobre os quais incidem, as normas deixam, ao aplicador, amplos espaços de análise discricionária a serem preenchidos conforme as avaliações políticas da autoridade competente.

A legitimidade da ponderação judicial, nesse viés, é igualmente questionada. Considerando que, tradicionalmente, a responsabilidade primária de ajustar interesses em conflito pertence ao Poder Legislativo, e tendo em vista que a proteção aos direitos humanos é resultado de ponderação de interesses, indaga-se se os juízes deveriam efetuá-la em substituição aos legisladores. Ao discordar, após sopesamento entre princípios, da decisão efetuada pelo legislador em um ato infraconstitucional, pode o juiz contrariar tal dispositivo legal e decidir de maneira diversa? Em caso afirmativo, o que lhe conferiria legitimidade para tal? A adoção do modelo ponderativo é suficiente para resguardar tal legitimidade? A adoção da proporcionalidade em sentido estrito dá azo à usurpação de competência legislativa pelo Judiciário?

Como substrato do modelo da ponderação de direitos fundamentais, encontra-se uma racionalidade e uma concepção de legitimidade que pretendemos, nesse trabalho, problematizar. O tema do ativismo judicial das Cortes constitucionais desafia as democracias constitucionais em seus próprios fundamentos: o dualismo entre Lei e Política no âmbito da tomada de decisões judiciais. A noção de racionalidade sob a qual se erige a forma como as Cortes decidem reverbera, nesse sentido, sobre o tema da legitimidade democrática de tais decisões.

Emerge, pois, a questão de se analisar se a tentativa de racionalização empreendida pelos teóricos da ponderação de princípios seria apta a legitimar a tomada de decisões políticas pelas Cortes constitucionais, ou se, ao contrário, tal tentativa apenas oferece uma roupagem jurídico-objetiva a uma decisão que é, em si mesma, política.

A fim de melhor enquadrar o tema do ativismo judicial, tal como assumido pelo STF, na esteira do Tribunal Constitucional Federal alemão, no conflito entre democracia e constitucionalismo, este trabalho pretende, por meio dos marcos teóricos inscritos nos modelos "discursivo" de Jürgen Habermas (2001) e "agonístico" de Chantal Mouffe (2009), desconstruir o conceito de racionalidade que está por trás de tais movimentos de ativismo judicial, bem como problematizar a ideia de legitimidade que é substrato do modelo de ponderação de princípios delineado no bojo de tal ativismo. A racionalidade inscrita no modelo da ponderação é apta a abarcar o dualismo entre constitucionalismo e democracia?

$\mathrm{Na}$ análise de tal objeto, estudaremos, inicialmente, o pensamento de Robert Alexy (2005a; 2008) acerca da argumentação jurídica, por se constituir 
como uma das mais influentes interpretações da cultura constitucional alemã a tentar delinear uma metodologia para justificar racionalmente as dificuldades trazidas pela transição da jurisprudência do Bundesverfassungsgericht para o ativismo. A seguir, apontaremos as críticas formuladas a tal pensamento por Jürgen Habermas (2001) e Chantal Mouffe (2009), e, por meio delas, procederemos à desconstrução da ideia de legitimidade que é substrato do ativismo judicial fundado na ponderação de princípios.

\section{Ponderação COMO método de Resolução de CONFlitos ENTRE DiReitos FUNDAMENTAIS: RACIONALIDADE OU AUTOILUSÃO?}

\subsection{Estudo empírico-comparativo de dois casos da jurisprudência constitucional, alemã e da brasileira}

Nesse capítulo buscaremos, inicialmente, contextualizar o debate acerca da ponderação de princípios na jurisprudência do Tribunal Constitucional Federal alemão (Bundesverfassungsgericht - BVG) e do STF, por meio da apresentação, a título exemplificativo, de dois julgados: o Caso Lüth, tratado pelo BVG, e o Caso Ellwanger, tratado pelo STF. A partir das questões tratadas em tais casos, iniciaremos a análise teórica do princípio da proporcionalidade e da aplicação da ponderação no âmbito da proporcionalidade em sentido estrito.

\subsubsection{Caso Lüth - Tribunal Constitucional Federal alemão (Bundesverfassungsgericht - BVG)}

Lüth havia chamado o público alemão, assim como os proprietários de cinemas e distribuidores de filmes, a boicotarem as obras do cineasta Veit Harlan produzidas após 1945. Lüth fundamentou a necessidade do boicote no fato de Harlan ter sido diretor-artístico de filmes nazistas de propaganda política antissemita, tais como o filme "Judeu doce".

O Tribunal de $2 .^{a}$ Instância de Hamburg condenou Lüth a omitir cada chamada para o boicote, com fundamento no fato de que esse violaria o $\S 826$ do Código Civil alemão, que proíbe causar, "em um modo que infringe os bons costumes, um dano doloso a outrem". ${ }^{1} \mathrm{O}$ Tribunal Constitucional Federal, por sua vez, considerou prima facie a chamada de Lüth ao boicote como

1. § 826 do Código Civil alemão: "Quem, em um modo infringente contra os bons costumes, ocasiona dolosamente dano a um outro, está obrigado, para com o outro, ao ressarcimento do dano". Trad. Luís Afonso Heck (Alexy, 2005b, p. 335). 
protegida pela liberdade de manifestação de opinião, inscrita no art. 5, 1, da Lei Fundamental (Grundgesetz). ${ }^{2}$ Acrescentou, porém, que há três hipóteses, constitucionalmente dispostas no art. 5, 2, da Lei Fundamental, que limitam a liberdade de manifestação. ${ }^{3}$ A primeira delas é precisamente a existência de "leis gerais" que disponham a respeito. Segundo o Tribunal Constitucional Federal, nesse sentido, o § 826 do Código Civil alemão, no qual o Tribunal de 2. ${ }^{a}$ Instância de Hamburg fundamentara sua decisão, é uma lei geral no sentido disposto no art. 5, 2, da Lei Fundamental, e se constitui como um limite, portanto, à liberdade de manifestação (BverfGE 7, 198, 211 ff).

Segundo Alexy (2005b), analisando o caso, na hipótese de se seguir a "construção de regras", a solução da questão esgotar-se-ia na resposta a duas questões: a) a chamada ao boicote deve se subsumir ao conceito de manifestação de opinião?; e b) o § 826 do Código Civil é aplicável ao caso? (Alexy, 2005b, p. 336).

O Tribunal Constitucional Federal respondeu afirmativamente à primeira questão, entendendo que se trata de manifestação livre de opinião. Quanto à segunda questão, considerou que o § 826 do Código Civil será aplicável na hipótese em que a chamada ao boicote infringir os bons costumes. O Tribunal de 2. ${ }^{a}$ Instância de Hamburg entendera que tal chamada infringia a concepção de direito e de costumes do povo alemão e violava, portanto, o § 826 do Código Civil. Isso porque, segundo tal Tribunal, a chamada ao boicote visava impedir a reaparição de Harlan como criador de filmes, embora esse tivesse sido absolvido em procedimento penal contra ele movido por sua participação no filme "Judeu doce", bem como tivesse passado pelo procedimento de "desnazificação".

O Tribunal Constitucional Federal, entretanto, reputara não ser suficiente fazer essas duas subsunções isoladas. No entendimento de tal Corte, sempre que a aplicação de normas de Direito Civil (como o § 826, por exemplo) conduzir à limitação de um direito fundamental (como o direito à livre manifestação), deve-se efetuar uma ponderação entre princípios constitucionais

2. Art. 5, 1, da Lei Fundamental alemã: "Cada um tem o direito de manifestar e difundir livremente sua opinião em palavra, escrito ou imagem e de informar-se sem entraves em fontes genericamente acessíveis. A liberdade de imprensa e a liberdade de reportagem por radiodifusão e filme serão garantidas. Uma censura não tem lugar". Idem, ibidem.

3. Art. 5, 2, da Lei Fundamental alemã: "Esses direitos encontram suas barreiras nas prescrições das leis gerais, nas determinações legais para proteção à juventude e no direito da honra pessoal". Idem, ibidem. 
colidentes. No caso Lüth, o resultado da ponderação efetuada pela Corte constitucional apontou no sentido de que ao princípio da liberdade de opinião deve ser conferida primazia em face dos princípios em sentido contrário. Entendeu, portanto, que a cláusula "contra os bons costumes" no § 826 do Código Civil deve ser interpretada de acordo com essa prioridade. Em resumo: Lüth ganhou.

O caso Lüth reuniu, pois, três questões que informaram o Direito Constitucional alemão. A primeira diz respeito ao fato de que os direitos fundamentais têm não só o caráter de regras ("construção estreita e exata"), como também o de princípios ("construção larga e ampla"). Nesse viés, para Alexy (2005b), a garantia constitucional de direitos fundamentais não se esgotaria em uma garantia de direitos individuais clássicos de defesa do cidadão contra o Estado, mas personificaria um ordenamento de valores objetivo. Em julgamento posterior, o Tribunal Constitucional Federal expôs seu entendimento acerca do "ordenamento de valores objetivo" como sendo o conjunto de "princípios (...) que se expressam nos direitos fundamentais".

A segunda ideia trazida pelo caso Lüth, refere-se ao fato de que os princípios, como valores jurídicos fundamentais, valem não apenas na relação Estado-cidadão, mas também na relação cidadão-cidadão, em todos os âmbitos do Direito. Produz-se, portanto, um efeito de irradiação dos direitos fundamentais sobre todo o sistema jurídico. Por fim, a terceira ideia resulta da estrutura dos princípios e valores como diretrizes propensas a colidir, de modo que tal colisão somente por meio da ponderação poderia ser resolvida.

Reconhece-se um discurso axiológico na argumentação do Tribunal, ao mencionar a irradiação, sobre todo o ordenamento jurídico, de uma ordem objetiva hierarquizada de valores inscrita na Constituição. Robert Alexy (2005; 2008) tenta racionalizar tal discurso, reconstruindo a noção de valor por meio de seu conceito de direito fundamental como norma princípio, que implicaria em mandamentos de otimização. Voltaremos à tese do autor mais à frente.

\subsubsection{Caso Ellwanger - STF}

No julgamento do HC 82.424-2/RS, conhecido como o "Caso Ellwanger", o STF deparou-se com o conflito entre os direitos à isonomia e à dignidade em particular, a ofensa a estes por meio de afirmações racistas - e o direito à liberdade de expressão. O caso relaciona-se à publicação, pelo autor Siegfried Ellwanger, de livros cujo conteúdo foi considerado repleto de afirmações racistas e discriminatórias contra a comunidade judaica. Após o STJ denegar o habeas corpus, ao argumento de que estaria, no caso, configurado o crime de racismo, nos termos do art. 20 da Lei 7.716/1989, Siegfried Ellwanger interpôs 
novo habeas corpus, dessa vez ao STF. Na Corte Suprema, o writ foi denegado, por decisão da maioria dos ministros, ao fundamento de que os livros impugnados constituíam-se como uma apologia à discriminação contra a comunidade judaica.

No que concerne aos direitos fundamentais envolvidos no caso, deve-se, inicialmente, recordar que a liberdade de expressão é tutelada pelo art. 5. ${ }^{\circ}$, IV, da CF/1988. Em nossa realidade constitucional, há, ainda, norma expressa, inscrita no art. 5. ${ }^{\circ}$, XLII, que define o crime de racismo e o reputa imprescritível. Percebe-se, portanto, que o caso em análise envolveu uma discussão acerca dos limites da liberdade de expressão, quando em colisão com a norma constitucional que incrimina o racismo.

O debate acerca da ponderação entre tais direitos dá-se no contexto de colisão entre o direito à livre expressão e o princípio da isonomia, princípio esse que, na realidade constitucional brasileira, é radicalizado pela incriminação de práticas discriminatórias. Para tal, discutiu-se a extensão a ser conferida ao conceito de raça e à proteção contra o racismo (por exemplo, se o termo racismo, no contexto histórico brasileiro, deve se aplicar apenas quando os envolvidos são negros, como sustentou o Min. Moreira Alves).

Discutiu-se, ainda, se os livros impugnados seriam a manifestação de uma ideologia abarcada pela proteção à liberdade de expressão. É de especial interesse, nesse ponto, a análise do voto proferido pelo Min. Gilmar Mendes. O mencionado Ministro, partindo do pressuposto de que o antissemitismo é uma forma de racismo, procurou analisar se a tutela à liberdade de expressão poderia ser utilizada para desconstituir a incidência do respectivo crime. Para tal, considerou que dois princípios seriam o foco do caso: a liberdade de expressão e o direito a não discriminação, este considerado uma consequência do princípio da isonomia.

A partir da aplicação do princípio da proporcionalidade, e com fulcro na obra Teoria dos direitos fundamentais, de Robert Alexy (2008), por meio da ponderação entre princípios, o Ministro asseverou que todos os direitos básicos possuem uma "essência intocável", cuja restrição encontra limite na incidência do princípio da proporcionalidade. Para tal, faz-se necessário ponderar o peso relativo de cada princípio que se encontrar em colisão, em face de determinado caso concreto.

Assim, o citado Ministro considerou que a incriminação das afirmações antissemitas era: (a) adequada, pois resguardava uma sociedade pluralista em que reina a tolerância, bem como tutelava a dignidade humana, inscrita no art. $1 .^{\circ}$, III, da CF/1988, e o pluralismo político, inscrito no art. 1. ${ }^{\circ}$, V, da CF/1988; (b) necessária, porque não havia nenhum outro meio menos nocivo e igualmente 
eficiente para tal, bem como pelo fato de que a condenação foi determinada em termos razoáveis; (c) proporcional em sentido estrito, pois se verificou a proporcionalidade entre o fim perseguido (a preservação da dignidade humana e dos valores inerentes a uma sociedade pluralista) e os limites impostos à liberdade de expressão do autor dos livros impugnados. Concluiu, pois, que houve um abuso no exercício de tal liberdade, a qual não abarca a possibilidade do exercício de atos de intolerância racial ou incitação à violência.

O Min. Marco Aurélio, por sua vez, utilizou-se, igualmente, do princípio da proporcionalidade, para, surpreendentemente, defender o argumento oposto. Interpretando o contexto histórico brasileiro, o mencionado Ministro sustentou que a liberdade de expressão, por ser fundamentada no princípio democrático, poderia apenas ser legitimamente restringida no aspecto relativo ao modo pelo qual um indivíduo expõe suas ideias, não quanto ao conteúdo em si de tais ideias.

Assim, o Ministro entendeu que a condenação do autor dos livros pela prática de racismo era: (a) inadequada, porque a proibição de publicação das obras em nada contribuiria para fazer cessar o antissemitismo; (b) desnecessária, pois não era o meio menos agressivo para tutela da isonomia no caso; (c) desproporcional em sentido estrito, porque o conteúdo dos livros impugnados nunca seria capaz de levar a uma "revolução na sociedade brasileira" no sentido da discriminação de judeus, enquanto, simultaneamente, eliminava por completo o exercício da liberdade de expressão do autor das obras.

Para o Ministro, portanto, por aplicação do princípio da proporcionalidade, a simples publicação de livros, ainda que de conteúdo discriminatório, não poderia ser considerada como abuso do exercício da liberdade de expressão, em face da impossibilidade de tais livros representarem perigo iminente de extermínio do povo judeu, especialmente em um país que nunca cultivou sentimentos antissemitas.

Necessário sublinhar, portanto, que a aplicação do mesmo método, a ponderação tomada no contexto do princípio da proporcionalidade, levou a resultados díspares entre os julgadores, oscilando conforme a ênfase dada ora na liberdade de expressão (Min. Marco Aurélio), ora na isonomia (Min. Gilmar Mendes), o que lança dúvidas sobre a possibilidade de a ponderação elevar o risco de decisões e valorações arbitrárias, e conduzir à relativização discricionária de direitos fundamentais.

A seguir, a fim de melhor contextualizar as questões debatidas nos casos acima analisados, analisaremos a teorização, elaborada pelo Tribunal Constitucional Federal alemão e pela doutrina germânica, sobre o critério da proporcionalidade. 


\subsection{O critério da proporcionalidade como método para justificação de intervenções em direitos fundamentais e solução de colisões}

Como relatado, conceito de proporcionalidade foi elaborado pela jurisprudência do Tribunal Constitucional Federal alemão. Nos termos de decisão prolatada na década de 1960, o "princípio" da proporcionalidade "resultaria da própria substância dos direitos fundamentais" (Martins, 2005, p. 233-245). Em seguida, afirmou o Tribunal que a proporcionalidade, apesar de não positivada no texto constitucional, possui status constitucional, derivada do Estado de Direito.

A jurisprudência do Tribunal Constitucional Federal alemão desenvolveu-se, pois, no sentido de apenas admitir intervenções em direitos humanos na medida em que estas estejam em consonância com o princípio da proporcionalidade. Paralelamente, o emprego de técnicas abertas de ponderação tem permitido, nesse viés, o aumento da intensidade de intervenção do Poder Judiciário no campo das decisões sobre direitos fundamentais (Dimoulis; Martins, 2011, p. 169).

Buscando sistematizar a jurisprudência do Tribunal, a doutrina debruçou-se na busca da racionalização metodológica da aplicação da proporcionalidade em casos de colisão de direitos. Outrossim, a concepção segundo a qual o texto constitucional relativo aos direitos fundamentais ofereceria um sistema objetivo de valores fortaleceu a tese da proporcionalidade em sentido estrito entendida como ponderação de bens. Nesse viés, o exame de proporcionalidade compreenderia natureza classificatória dos bens envolvidos (adequação), eliminatória (necessidade) e axiológica (proporcionalidade em sentido estrito), caracterizando-se por um afunilamento progressivo. Nesse âmbito, a proporcionalidade em sentido estrito compreenderia uma ponderação axiológica entre dois bens jurídicos em conflito (Dimoulis; Martins, 2011, p. 173).

A recepção do exame de proporcionalidade é, no Brasil, caracterizada por certa imprecisão e sincretismo. Em geral, a ideia de proporcionalidade é reduzida a um mero exame de razoabilidade, intrínseco à tradição do common law. Em muitas interpretações, a proporcionalidade é reduzida à condição de mero instrumento retórico do método da interpretação teleológica de uma relação entre meios e fins, como indicação do vínculo lógico entre uma providência legislativa e a finalidade por ela visada. A ponderação é apresentada, assim, como método ao qual se recorre, na hipótese de não mais ser possível decidir mediante a aplicação de uma norma (Dimoulis; Martins, 2011, p. 176-177).

A proporcionalidade em sentido estrito sugere a metáfora da balança, na qual se efetua uma ponderação entre valores, a fim de que os pesos respectivos 
sejam valiados, devendo prevalecer o valor que, no caso concreto, apresentar maior importância. Procurou-se, pois, no sistema constitucional alemão, a fixação de um sistema axiológico, uma escala de valores constitucionais que servisse de medida para a ponderação e a racionalizasse (Dimoulis; MarTins, 2011, p. 210).

Nessa esteira, Robert Alexy (2008) buscou racionalizar a ponderação, elaborando uma teoria principiológica dos direitos fundamentais. O autor concebe, como tarefa da proporcionalidade em sentido estrito, a otimização jurídica dos direitos, em contraposição à otimização fática, realizada por meio dos exames da adequação e da necessidade. A proposta de Alexy (2005; 2008) insere, portanto, na ponderação, além do sopesamento axiológico, elementos fáticos ligados ao caso concreto (Dimoulis; Martins, 2011, p. 211).

Analisaremos, a seguir, o pensamento do jurista de Kiel. Antes, porém, faremos uma breve incursão no pensamento kelseneano acerca da interpretação jurídica, a fim de contextualizar a questão que a proposta de Alexy (2005) busca solucionar: a subjetividade do julgador na emissão de decisões jurídicas.

\section{Argumentação jurídica no pensamento de Robert Alexy}

\subsection{A constatação de um problema: a interpretação jurídica como moldura no pensamento de Hans Kelsen}

De conformidade com sua concepção do ordenamento jurídico como estrutura de normas hierarquizadas, Hans Kelsen (1999) sustenta que há uma relação de determinação incompleta entre os escalões de tal estrutura. A norma do escalão superior regula o ato através do qual é produzida a do inferior e tem caráter de moldura a ser preenchida pelo ato de produção normativa que a aplica. A norma individual que resulta da aplicação da norma geral continua o processo de determinação que constitui o sentido da estrutura escalonada da ordem jurídica. Resta sempre, porém, uma margem de apreciação para o intérprete: todo ato jurídico em que o Direito é aplicado é, em parte, determinado e, em parte, indeterminado (KELSEN, 1999, p. 388).

Tal indeterminação pode ser consequência não intencional da utilização, pela norma a ser aplicada, de palavras que comportem uma pluralidade de significações. Nesta hipótese, oferecem-se ao intérprete, através de uma atividade meramente cognoscitiva de fixação da moldura legal, várias possibilidades de aplicação igualmente conformes ao Direito. Através de uma atividade de apreciação subjetiva de tais possibilidades, o intérprete emite o ato aplicador, 
escolhendo uma entre as soluções que se inserem no interior da moldura legal oferecida pela norma a ser aplicada. ${ }^{4}$

Destarte, para tal autor, à interpretação cognoscitiva (que permite o conhecimento das várias possibilidades de normas de escalão inferior que podem ser produzidas com base na mesma norma de escalão superior) combina-se um ato de vontade em que o órgão aplicador efetua uma escolha, segundo critérios extralegais, de apenas uma das possibilidades presentes dentro dos limites legais, a qual se tornará, assim, direito positivo. Tal escolha será, pois, autêntica, pelo fato de criar Direito. Depreende-se, portanto, dos ensinamentos do jurista austríaco, que a interpretação também envolve um momento de escolha entre indiferentes jurídicos. A interpretação e a solução adotadas pelo juiz envolvem, pois, ponderação valorativa e escolha política do aplicador para subsumir ou não os fatos à norma.

\subsection{Linhas centrais do pensamento de Robert Alexy}

Como visto, no que concerne à aplicação do Direito, o positivismo jurídico, sobretudo a partir de Kelsen e Hart, diagnosticou corretamente a textura aberta do Direito, ou seja, o fato de que o processo de interpretação e aplicação do direito não leva a uma única resposta correta, mas, pelo contrário, conduz a uma pluralidade de soluções igualmente admitidas dentro da moldura jurídica conformada pelas regras e princípios contidos no ordenamento. Trata-se do chamado "poder discricionário" do aplicador do direito. O positivismo jurídico não cuidou, porém, de desenvolver teorias interpretativas que solucionassem ou minimizassem tal problema. A Teoria da argumentação jurídica. de Alexy (2005a), por sua vez, volta-se precisamente para o problema da argumentação legal, da interpretação do direito. Partindo da premissa segundo a qual a aplicação jurídica conduz a uma pluralidade de soluções, tal teoria trata de analisar as razões pelas quais uma ou outra solução é adotada, e busca formular o procedimento para tal. Tal teoria busca, portanto, delinear os meios de racionalização do processo de interpretação jurídica.

Nesse passo, a diferença entre a concepção de Alexy (2005a) e o positivismo reside na concepção acerca da fundamentação do direito. No positivismo, o

4. "A questão de saber qual é, de entre as possibilidades que se apresentam nos quadros do Direito a aplicar, a 'correta', não é sequer - segundo o próprio pressuposto de que se parte - uma questão de conhecimento dirigido ao Direito positivo, não é um problema de teoria do Direito, mas um problema de política do Direito." (Kelsen, 1999, p. 393). 
fundamento de validade do direito é formal (no sentido de que não há determinação do conteúdo da norma) e não reside, pois, em normas morais. Diferentemente, para Alexy (2005a), o fundamento do direito não é nem formal (como no positivismo), nem material (como no jusnaturalismo): tal fundamento é procedimental. O direito ganha, assim, uma dimensão moral que não significa a crença em uma ordem natural, mas sim a ideia de que a legitimidade do ordenamento jurídico depende do procedimento de sua produção e aplicação, que deve ser democrático e racionalizado.

Alexy (2005a) parte de uma teoria da argumentação prática geral e a projeta, posteriormente, para o campo do Direito. Sua tese central consiste, pois, em considerar o discurso jurídico como um caso especial do discurso prático geral. Em ambos, está-se a tratar da correção de enunciados normativos. No discurso jurídico, porém, a argumentação é limitada por uma série de condições: a sujeição à lei, a consideração obrigatória dos precedentes e o enquadramento na dogmática elaborada pela Ciência Jurídica.

A Teoria do discurso de Habermas (2001) exerceu influência fundamental sobre a teoria formulada por Alexy (2005a). Esta significa, por um lado, uma sistematização e reinterpretação da teoria habermasiana do discurso prático, e, por outro lado, uma extensão dessa tese para o campo do Direito. Explica-se. Habermas (2001) parte de um conceito amplo de razão, a partir do qual sustenta a tese de que as questões práticas podem ser decididas racionalmente, por meio da força do melhor argumento. O resultado do discurso prático pode ser, pois, racionalmente motivado, e pode exprimir um consenso fundado e uma vontade racional. Como consequência, as questões práticas são suscetíveis de verdade em sentido amplo, fixado no bojo de uma teoria consensual de verdade, que se contrapõe à teoria da verdade como correspondência entre enunciados e fatos.

$\mathrm{Na}$ concepção consensual de Habermas (2001) e na concepção de Alexy (2005a), a condição de verdade de um enunciado é o assentimento potencial de todos os partícipes do discurso. Em sentido amplo, portanto, enunciados normativos são verdadeiros ou falsos. Em sentido estrito, são corretos ou incorretos. A correção das normas depende, em última instância, de que se possa alcançar o consenso em uma situação de total liberdade e simetria entre os partícipes do discurso: a situação ideal de fala ou de diálogo. A argumentação não é considerada, pois, apenas uma série de proposições, mas uma série de atos de fala: um tipo de interação, de comunicação. Nesse contexto, a validade da norma reside no assentimento de todos os partícipes do discurso, obtido por meio de um procedimento em que são garantidas a autonomia e a igualdade entre tais participantes. 
A teoria do discurso de Habermas (2001), da qual parte Alexy (2005a), pode ser caracterizada, portanto, como uma teoria do procedimento, no sentido de que um enunciado normativo é correto e válido apenas se for resultado de um procedimento marcado pela liberdade e pela simetria características da situação ideal de fala. As exigências de simetria e liberdade, propostas por Habermas (2001), constituem o conteúdo das regras do discurso racional denominadas por Alexy (2005a) como regras da razão. Estas não se referem apenas às proposições, mas também ao comportamento do falante, pois são regras semânticas e pragmáticas. Alexy (2005a) estabelece, pois, uma série de exigências da atividade de fundamentação, ou seja, regras da discussão racional, cujo cumprimento garante que, como resultado, a norma que se pretende fundamentar seja racional. As regras do discurso não garantem, porém, que se possa alcançar um acordo para cada questão prática, nem que se possam resolver todos os problemas de conhecimento, nem que, caso alcançado tal acordo, todos estejam dispostos a cumpri-lo.

Assim, tem-se que, para Alexy (2005a), o discurso jurídico é um caso especial do discurso prático geral, o que significa que: (a) nele se discutem questões práticas; (b) nele se erige uma pretensão de correção; e que (c) isso se faz dentro de determinadas condições. O discurso jurídico não pretende sustentar que uma determinada proposição seja mais racional, mas sim que ela pode ser fundamentada racionalmente na moldura do ordenamento jurídico vigente.

O discurso jurídico tem também seus limites. Na teoria de Alexy (2005a), uma solução que tenha sido alcançada com respeito às regras do discurso jurídico é uma solução racional, mas tais regras não garantem que, em cada caso, chegue-se a uma única resposta correta. Diante de um mesmo caso, as regras do discurso jurídico permitem que seus partícipes cheguem a conclusões racionais (fundamentadas discursivamente), mas incompatíveis entre si. Isso se dá por uma série de motivos: o discurso se inicia com fundamento em convicções dos participantes; nem todos os passos da argumentação estão determinados; algumas regras do discurso só podem ser satisfeitas de modo aproximado. Assim, a pretensão de correção que se propõe no discurso jurídico é não só limitada (às exigência legais, à dogmática, aos precedentes, às regras do discurso jurídico), como também relativa aos participantes do discurso (a suas convicções normativas) e a determinado momento temporal. A teoria do discurso é, pois, um procedimento para o tratamento racional das convicções normativas dos participantes faticamente existentes.

\subsection{Ponderação, racionalidade e princípios}

Confrontado, pois, com a constatação contemporânea de que a aplicação de normas jurídicas não é uma simples subsunção lógica de normas abstratas a 
casos concretos, Robert Alexy (2005a) impõe-se a tarefa de responder à questão de como podem ser fundamentadas as decisões jurídicas, considerando que essas compreendem uma ponderação de valores. Surge, pois, a questão de se saber onde e em que medida são necessárias tais valorações, como deve ser determinada a relação entre elas e como podem ser racionalmente fundamentadas. A resposta a tal questão tem grande peso no problema da legitimidade da regulação de conflitos sociais mediante decisões judiciais.

$\mathrm{O}$ autor adverte, porém, que do fato de que não se poderia prescindir de valorações não se deve deduzir que, na medida em que essas são necessárias, haveria um campo livre para as convicções morais subjetivas dos aplicadores do Direito. Tal conclusão só seria válida se não existisse em absoluto a possibilidade de objetivar tais valorações. Essa é uma tarefa difícil, na medida em que há diferentes concepções para os problemas práticos, os consensos fáticos são raros e de tais juízos fáticos não se podem extrair premissas normativas. Mesmo no conjunto de um ordenamento podem ser encontradas valorações divergentes, e o Direito não é indiferente às razões pelas quais ou o modo pelo qual um juiz decide. Na resposta a tais questionamentos, têm sido propostas três vias; (a) a ideia de que quem decide deve ajustar-se aos "valores da coletividade ou de círculos determinados"; (b) o recurso ao "sistema interno de valorações do ordenamento"; (c) o apelo a uma "ordem concreta de valores".

Emerge a questão, pois, de se saber qual a relação entre a argumentação jurídica e a argumentação prática geral. Três respostas seriam possíveis para tal questão: (a) a tese da subordinação, segundo a qual o processo de fundamentação deve realizar-se segundo os critérios do discurso prático geral, e a fundamentação jurídica só atua como legitimação secundária do resultado obtido de tal maneira, de modo que o discurso jurídico seria apenas um discurso prático geral com uma fachada jurídica; (b) a tese da adição, pela qual a argumentação jurídica chega até determinado ponto em que já não são possíveis argumentos especificamente jurídicos, e nesse momento entra em jogo a argumentação prático-geral; (c) a tese da integração, defendida por Alexy (2005b), segundo a qual o uso de argumentos especificamente jurídicos deve unir-se aos argumentos práticos gerais, em todos os níveis.

Para o autor, o discurso jurídico não pode se mover de modo autossuficiente no interior de um universo hermeticamente fechado de Direito positivo vigente, mas deve permanecer aberto a argumentos de outras origens (pragmáticos, éticos, morais). Entende, ainda, que a correção das decisões judiciais é medida pelo grau de cumprimento das condições comunicativas da argumentação que possibilitam um julgamento imparcial.

No que concerne à estrutura das normas constitucionais, portanto, entende o autor que o problema das relações de prioridade entre princípios corres- 
ponde ao problema de uma hierarquia de valores, no sentido de que os princípios, assim como os valores, teriam um código gradual e não binário, como as regras, e podem ser cumpridos em diferentes graus. Alexy (2005a) parte, assim, de uma distinção qualitativa entre regras e princípios, segundo a qual a generalidade não é um critério adequado para apartar as noções de regras e princípios. Segundo o autor, a distinção entre tais tipos de normas reside na estrutura das mesmas.

Nesse modelo, as regras são aplicáveis segundo a lógica do "tudo ou nada", o que significa que, se uma regra é válida, deve ser aplicada do modo como preceitua, conforme um procedimento de subsunção silogístico. Em face de um conflito entre regras, uma delas será inválida, salvo no caso de se encontrar em situação em que excepciona a outra. Os princípios, diferentemente, possuem uma dimensão de peso, e, quando em conflito, apresentam razões argumentativas em favor de uma ou outra solução. A aplicação de princípios exige, portanto, um procedimento de ponderação, de modo que, em face de uma colisão, o valor decisório seja dado ao princípio de que tiver maior peso relativo no caso concreto, sem que isso signifique a invalidação do princípio de peso menor. Para Alexy (2005a; 2008), portanto, princípios são normas que ordenam que algo se realize na maior medida possível, consideradas as condições jurídicas e fáticas de determinado caso. São mandados de otimização, e podem ser cumpridos em diferentes graus. Diferentemente, as regras exigem cumprimento pleno e contêm determinações no campo do possível fático e jurídico. "Em face de um outro caso, portanto, o peso dos princípios poderá ser redistribuído de maneira diversa, pois nenhum princípio goza antecipadamente de primazia sobre os demais" (PEDron, 2005, p. 71).

Como explicar, portanto, a natureza de mandados de otimização atribuída aos princípios? Como uma norma pode ter sua aplicação em diferentes graus? Para Alexy (2005a; 2008), isso se explica quando os princípios são equiparadas a valores, o que traz uma referência não no campo do "dever ser" (deontológico), mas no campo do que pode ou não ser considerado como bem (axiológico). Os valores permitem que determinado juízo possa ser classificado, comparado ou medido. Sublinhe-se: para o autor, princípios não são valores, porque apontam para o que é devido, enquanto os valores apontam para o que pode ser considerado o melhor. Não obstante, princípios se equivalem a valores, no sentido de que ambos possuem operacionalização idêntica. Os princípios são, pois, normas que comandam a realização de valores.

À oposição entre "construção de regras" e "construção de princípios" soma-se a oposição entre um "modelo de subsunção" e um "modelo de ponderação". Alexy (2005b) indaga-se, portanto, qual dos dois modelos e construções conduz a mais racionalidade na jurisprudência constitucional (Alexy, 2005b, p. 337). 
Como nem os princípios, nem as regras são capazes de regular por si sós sua própria aplicação, entende o autor ser necessária a compreensão da decisão jurídica regrada por uma teoria da argumentação jurídica. Para Alexy (2005a; 2008), portanto, a questão da resposta correta resume-se no desenvolvimento de um procedimento que conduza a uma decisão racional.

Percebe-se, pois, que Alexy (2005a; 2008), na formulação de seu pensamento, combina uma teoria dos princípios e uma teoria da argumentação orientada pelo conceito de razão prática. Alexy (2005b) indaga-se, nesse ponto, se o ponderar seria, em si mesmo, irracional, e se a ponderação seria incapaz de impedir o sacrifício de direitos individuais. A fim de responder a tais questões, o autor passa à análise da estrutura da ponderação. Afirma o autor, nessa esteira, que a ponderação é parte de algo que é exigido pelo princípio mais amplo da proporcionalidade. Esse, por sua vez, compreende três princípios parciais que expressam a ideia de otimização: (a) a idoneidade; (b) a necessidade; e (c) a proporcionalidade em sentido estrito. Nesse sentido, direitos fundamentais como princípios são mandamentos de otimização e, como tal, são normas que ordenam que algo seja realizado, relativamente às possibilidades fáticas e jurídicas, na maior medida possível (Alexy, 2005b, p. 338-339).

Os princípios da idoneidade e da necessidade tratam da otimização relativamente às possibilidades fáticas. O primeiro exclui o emprego de meios que prejudiquem a realização de, pelo menos, um princípio, sem fomentar outro. Nesse sentido, se um meio M não é idôneo para fomentar a realização do princípio P1 e ainda prejudica a realização do princípio $\mathrm{P} 2$, tem-se que o meio $\mathrm{M}$ deve ser abandonado. O princípio da necessidade, por sua vez, determina que, de dois meios que fomentem igualmente o princípio $\mathrm{P} 1$, deve-se escolher aquele que menos intensamente intervém em P2. A aplicabilidade da necessidade pressupõe, todavia, que não existe um princípio P3 que, pelo emprego de tal meio, é afetado negativamente. Nesse caso, se custos e sacrifícios não podem ser evitados, deve-se recorrer à ponderação (Alexy, 2005b, p. 339).

A ponderação é objeto do terceiro princípio, o da proporcionalidade em sentido estrito, o qual diz o que significa a otimização relativamente às possibilidades jurídicas, conforme a "lei da ponderação", segundo a qual, "quanto mais alto é o grau do não cumprimento ou prejuízo de um princípio, tanto maior deve ser a importância do cumprimento do outro". Assim, para Alexy (2005a; 2008), otimizar nada mais é do que ponderar. Segundo o autor, a "lei da ponderação" revela que a ponderação decompõe-se em três etapas: (a) primeiramente, deve-se comprovar o grau de não cumprimento ou prejuízo de um princípio; (b) após, deve-se comprovar a importância do cumprimento do princípio contrário; e (c) por fim, deve-se comprovar se a importância do 
cumprimento do princípio contrário justifica o prejuízo ou não cumprimento do outro (Alexy, 2005b, p. 339-340).

Como vimos, por meio da análise do percurso histórico tomado pela jurisprudência do Tribunal Constitucional Federal alemão, pode-se perceber que, a partir do momento em que tal Corte começa a apresentar uma forte tendência ao ativismo judicial, emerge a controvérsia quanto à legitimidade de suas decisões, o que enseja, na doutrina, uma busca intensa por uma racionalidade metodológica apta a justificar tal prática. $\mathrm{Na}$ Corte, os direitos deixam de ser concebidos como subjetivos, e passam a ser entendidos como princípios de uma ordem jurídica objetiva e total, passíveis de otimização e ponderação.

Entre os teóricos do Direito, o objetivo de racionalizar a ponderação de princípios acompanha esse movimento em direção à judicialização da política. De fato, na esteira da jurisprudência do BVG, Robert Alexy (2005a) desenvolve sua teoria da argumentação jurídica, sustentada, em linhas gerais, por quatro vertentes: (a) a concepção do discurso jurídico como caso especial do discurso prático geral; (b) a relativização do caráter deontológico dos princípios, seguida da; (c) tentativa de justificação racional de tal fato por meio do emprego de critérios objetivos; e, por fim, (d) a noção de "representação argumentativa", como fundamento da legitimidade das decisões tomadas conforme tais critérios.

Procederemos, a seguir, à crítica da teoria da argumentação jurídica de Alexy (2005a) por meio de duas vertentes: os pensamentos de Jürgen Habermas (2001) e Chantal Mouffe (2009).

\section{SOBRE OS LIMITES dA ARGUMENTAÇÃO JURÍDICA: DESCONSTRUINDO A PONDERAÇÃO DE PRINCÍPIOS E O ATIVISMO JUDICIAL}

Paralelamente aos movimentos teóricos que buscaram justificar a virada do BVG rumo ao ativismo judicial e a adoção da ponderação de princípios, diversos pensadores voltaram-se criticamente contra os fundamentos teóricos da jurisprudência formada naquela Corte. Inicialmente, apresentaremos as críticas endereçadas por Jürgen Habermas (2001) à teoria da argumentação jurídica de Alexy (2005a), no que concerne à subordinação do Direito à Moral, bem como suas críticas quanto à relativização do caráter deontológico dos princípios.

\subsection{A crítica habermasiana ao modelo de ponderação}

\subsubsection{O modelo discursivo de Jürgen Habermas}

De início, é necessário pontuar que, em fase anterior à da formulação da Teoria Discursiva do Direito, Jürgen Habermas lecionava que a esfera jurídica 
encontrava-se de tal modo atrelada à esfera moral, que se reduzia a um apêndice desta. A medida de legitimidade do Direito e sua fundamentação eram extraídas a partir do apelo à Moral, a qual era, pois, sua matriz interpretativa. As questões morais permeariam as questões jurídicas e seriam institucionalizadas por meio de procedimentos jurídicos. Pressupunha-se, assim, uma relação de dependência e submissão do Direito em relação à Moral (Moreira, 2004, p. 193).

Diferentemente, na Teoria Discursiva do Direito, tal como formulada por Habermas, o Direito não se encontra a priori atrelado à Moral, mas ambos originam-se simultaneamente. Há uma relação, pois, de cooriginariedade entre Direito e Moral. Apenas por meio do procedimento, dá-se o entrelaçamento a posteriori entre as duas esferas (MoreIRA, 2004, p. 194). Rompe-se com a razão prática, que é substituída pela razão comunicativa. Esta não é informativa para a ação, na medida em que não há o recurso a uma normatividade a priori que oriente a ação. Nesse sentido, diz-se que a razão comunicativa não é imediatamente normativa, mas apenas o é mediatamente, na medida em que apenas se torna prescritiva após ser estabelecida por um consenso discursivamente formado (Moreira, 2004, p. 137 e 141).

Assim, como não há uma normatividade imediata à qual possa se remeter, a fundamentação do Direito deixa de apelar à Moral. Em uma sociedade plural, em que convivem diferentes concepções de mundo e a autoridade do sagrado e do costume se esfacelam, a integração social torna-se precária, na medida em que, sem o recurso a uma autoridade moral ou metafísica estabelecida, sempre há a possibilidade do dissenso (Moreira, 2004, p 142). O Direito passa, pois, a assumir o papel principal na resolução dos problemas de integração social, no sentido de que, por meio dele, são institucionalizadas as aspirações, vontades e opiniões dos cidadãos. Em tal processo de institucionalização, as razões que guiam as ações individuais apenas revestem-se de obrigatoriedade ao serem capazes de resistir aos questionamentos contra elas formulados no procedimento democrático.

Isso significa, como já explicitado, que a normatividade de tais razões deixa de ser imediata e torna-se mediata, no sentido de que passa a ser procedimental: a resolução dos problemas desliga-se da tradição e da esfera moral do indivíduo, e atrela-se ao procedimento discursivo, no qual apenas a normatividade do melhor argumento adquire obrigatoriedade (MoreIrA, 2004, p. 194). O Direito institucionaliza-se, assim, por meio de um procedimento que emana da complementaridade e cooriginariedade entre direitos humanos e soberania política. A validade de tal procedimento, por sua vez, é sempre passível de ser problematizada, abrindo espaço para a revogação da norma por meio dele pro- 
duzida, cuja validade é, portanto, sempre falível (Moreira, 2004, p. 137-138). Assim, tem-se que a legitimidade do Direito decorre da correção do procedimento, a qual, por sua vez, resulta da conjugação entre direitos humanos e soberania política.

Para tal conjugação, Habermas articula um princípio deontologicamente neutro do discurso, no sentido de que recusa a subordinação do Direito positivo ao Direito Natural e repele a complementaridade entre as esferas jurídica e moral. Habermas fundamenta o Direito por meio de tal princípio do discurso, deontologicamente neutro, a fim de estabilizar a tensão entre as autonomias privada e pública por meio do procedimento (MOREIRA, 2004, p. 138-139).

Para Habermas (1998a), os cidadãos são politicamente autônomos somente quando podem ser entendidos conjuntamente como autores das leis às quais se submetem como destinatários. A relação dialética e a reciprocidade entre as autonomias pública e privada se fundam, pois, no fato de que: (a) não há direito sem liberdades subjetivas reclamáveis juridicamente que garantem a autonomia privada das pessoas individuais; (b) não há direito legítimo sem legislação democrática comum de cidadãos legitimados a participarem como livre e iguais em tal processo (HABERMAS, 1998a, p. 69-70).

Segundo Habermas (1998b), tudo o que tem validade publicamente deve poder se justificar também publicamente. Enquanto as partes podem assentir cada uma por razões distintas, os partícipes em uma argumentação devem conseguir o acordo racionalmente motivado a partir das mesmas razões, em um consenso alcançado pública e coletivamente (HABERMAS, 1998b, p. 161). Nesse viés, Habermas propõe superar as tradições político-filosóficas liberal e republicana por meio da noção de cooriginalidade entre direitos humanos e soberania popular, entre as autonomias pública e privada, o que culmina na concepção procedimental do Estado Democrático de Direito (Habermas, 2001, p. 160 e ss.). Segundo o autor, "la conexión interna que buscamos entre soberanía popular y derechos del hombre ha de radicar, pues, en el contenido normativo de un modo de ejercicio de la autonomía política, que no viene asegurado por la forma de leyes generales sino sólo por la forma de comunicación que representa la formación discursiva de la opinión y la voluntad comunes" 5 (Habermas, 2001, p. 168).

5. "A conexão interna que buscamos entre soberania popular e direitos humanos há de radicar, pois, no conteúdo normativo de um modo de exercício da autonomia política, que não vem assegurado por meio de leis gerais, mas somente por meio de uma comunicação que representa a formação discursiva da opinião e da vontade comum" (trad. livre da autora). 
Pela concepção, pois, dos destinatários simultaneamente como autores de seus direitos, delineia-se a cooriginalidade entre as autonomias pública e privada, no sentido de que nenhuma delas se sobrepõe à outra, porquanto ambas se pressupõem mutuamente. O princípio da soberania popular, pelo qual toda autoridade estatal decorre do povo, remete ao direito subjetivo de todos os cidadãos à participação com igualdade de condições na formação democrática da vontade comum.

Segundo o princípio do discurso (D), "D: Válidas son aquellas normas (y solo aquellas normas) a las que todos los que puedan verse afectados por ellas pudiesen prestar su asentimiento como participantes en discursos racionales"6 (Habermas, 2001, p. 172). Assim, os indivíduos, ainda que em sua condição privada, podem iniciar um debate que se torna público simplesmente por meio de suas regras, da implementação do princípio (D). O público constitui-se como tudo aquilo que resulta do processo de compartilhamento em público, sob determinadas regras. Todo o sistema de direitos fundamentais, portanto, deriva-se da natureza discursiva da criação do direito.

Tem-se, desse modo, um duplo aspecto na relação entre normas morais e jurídicas: simultaneidade na origem e complementaridade procedimental. Enquanto, em sua origem, a relação entre Direito e Moral é de simultaneidade/ cooriginariedade, diferentemente, em seu procedimento, tal relação é de complementaridade recíproca. Isso significa, primeiramente, que a simultaneidade genética das duas esferas preserva a independência entre elas, por meio do princípio do discurso. Por outro lado, por meio do procedimento, a complementaridade entre as esferas garante à Moral uma "irradiação para além de suas fronteiras" e permite ao Direito uma "abertura do mundo jurídico ao universo moral" (Moreira, 2004, p. 150 e 158).

Tal transformação na relação entre Moral e Direito significa a secularização deste último, o qual passa a retirar sua fundamentação por meio da conformação à vontade discursivamente formada entre os cidadãos. A medida de legitimidade do Direito desliga-se, portanto, da esfera moral e atrela-se nos procedimentos discursivos, passando a ser definida pelas razões do melhor argumento, o qual é sempre passível de problematização. O Direito passa, pois, a ser visto como produto e reflexo da vontade discursiva dos cidadãos. "Isto é, o Direito estabiliza a tensão entre facticidade e validade, pois sua validade precisa estar em condições de comprovar-se" (MOREIRA, 2004, p. 195).

6. "D: Válidas são aquelas normas (e só aquelas normas) às quais todos os que possam se ver por elas afetados possa prestar seu assentimento como partícipes em discursos racionais" (trad. livre da autora). 


\subsubsection{A crítica habermasiana à Teoria da Argumentação Jurídica}

Jürgen Habermas (1994) critica a tese de Alexy (2005a; 2008), segundo a qual a argumentação jurídica seria um caso especial da argumentação prático-moral em geral. Entende Habermas que tal tese relativiza a correção de uma decisão judicial, na medida em que a racionalidade da argumentação jurídica é sempre relativa à racionalidade da legislação, por ser determinada por leis. Sustenta Habermas (1994), ainda, que a tese do caso especial sugere uma subordinação do Direito à Moralidade que ainda porta conotações de Direito Natural.

Jürgen Habermas (1994) formulou diversas objeções ao modelo da ponderação. Afirma o filósofo que tal modelo retira a força normativa dos direitos fundamentais. Por meio da ponderação, tais direitos seriam reduzidos ao plano dos objetivos, programas e valores e perderiam sua "primazia rigorosa" característica dos "pontos de vista normativos". "Se, no caso de colisão, todos os fundamentos podem adquirir o caráter de argumentos de fixação de objetivos, cai exatamente aquele muro de fogo, que é posto no discurso jurídico com uma compreensão deontológica de princípios jurídicos e normas jurídicas" (Habermas, 1994, p. 315).

A tal perigo de enfraquecimento dos direitos fundamentais soma-se o perigo de juízos irracionais. Segundo Habermas (1994), não existem "critérios racionais" para o ponderar. "Porque para isso faltam critérios racionais, a ponderação efetiva-se ou arbitrariamente ou não refletidamente segundo modelos e ordens hierárquicas acostumados" (Habermas, 1994, p. 315).

Habermas (1994) entende, pois, que, no modelo da ponderação, o direito é retirado do âmbito do válido/inválido, correto/falso e do âmbito da fundamentação, e é transplantado para um âmbito definido por ideias como a de maior ou menor conveniência e por conceitos como o de poder discricionário. Assim, para o filósofo, a ponderação conduziria à perda da pretensão de correção, à qual o direito está, entretanto, necessariamente unido. Para Habermas (1994), a correção de uma norma está fundada na possibilidade de se atingir um consenso abrangente, capaz de ultrapassar as perspectivas particulares dos sujeitos envolvidos. A validade de uma decisão consiste no fato de que ela seria aceita, reconhecida como válida sob condições ideais de justificação (PEDRON, 2005, p. 75).

Habermas (1994) critica, ainda, a aproximação alexyana entre princípios e valores, ao fundamento de que, mediante tal aproximação, os princípios perderiam a característica de código binário para se transformarem em um código gradual. Deixa-se de falar em adequabilidade, e passa-se a falar em preferibilida- 
de, de modo que os princípios não mais indicam o que é devido, mas o que é preferível, e corre-se o risco de se confundir direitos com bens que podem ter sua aplicação negociada conforme as preferências da autoridade que decide.

Uma concepção axiológica das normas não apresenta, porém, o potencial de universalização contido nos discursos sobre a correção das normas, uma vez que está enraizada em preferências. Há, pois, no pensamento habermasiano, uma colonização do mundo da vida pelo Poder Judiciário, com a expansão da racionalidade instrumental, desalojando a racionalidade comunicativa e gerando uma crise de legitimidade do direito. Numa concepção deontológica, diferentemente, os falantes são retirados do contexto em que se encontram enraizados e podem analisar preferências a partir de uma perspectiva intersubjetiva abrangente (PEDRON, 2005, p. 75-76).

Um aspecto importante da teoria de Alexy (2005a; 2008), conexo com a história do Tribunal Constitucional Federal alemão, reside na atribuição de caráter teleológico aos princípios jurídicos, e na inserção de direitos no âmbito do discurso moral, por meio da tese do caso especial. No que concerne à estrutura das normas constitucionais, portanto, entende o autor que o problema das relações de prioridade entre princípios corresponde ao problema de uma hierarquia de valores, no sentido de que os princípios, assim como os valores, teriam um código gradual e não binário, como as regras, e podem ser cumpridos em diferentes graus. A aplicação de princípios exigiria, portanto, um procedimento de ponderação, de modo que, em face de uma colisão, o valor decisório seja dado ao princípio de que tiver maior peso relativo no caso concreto, sem que isso signifique a invalidação do princípio de peso menor. Como explicar, portanto, a natureza de mandados de otimização atribuída aos princípios? Como uma norma pode ter sua aplicação em diferentes graus? Para Alexy (2005a; 2008), isso se explica quando os princípios são equiparadas a valores.

A teoria da argumentação jurídica de Alexy (2008), como método decisório, baseia-se, nesse viés, na premissa não questionada segundo a qual a ponderação seria o resultado natural da diferenciação entre regras e princípios. Parte-se, assim, da premissa de que os princípios teriam um caráter de mandamentos de otimização, o que implicaria o princípio da proporcionalidade, e vice-versa. Princípios seriam equiparados a valores, e por isso seriam otimizáveis, e vice-versa. Tal premissa conduz, portanto, à conclusão irrecorrível de que a ponderação seria inevitável. Não se discute por que princípios deveriam ser concebidos dessa maneira, ou por que eles possuiriam esse atributo teleológico de serem realizados na maior medida possível. Por que a ponderação é uma consequência natural da natureza dos princípios? 
Essa é, como se vê, a estrutura de um sistema circular que justifica a si mesmo a partir de si mesmo, de suas próprias premissas. Transformam-se, pois, direitos constitucionais em princípios moralizadores, o que coloca em risco o caráter deontológico de tais direitos: the force of law. Por meio de tal viés moralizador, não há reinvenção, mas sim a manutenção de uma identidade constitucional.

Trata-se, como se percebe, de uma abordagem substantiva da argumentação, na medida em que se faz necessário estabelecer um parâmetro moral subjacente aos princípios, em caso de colisão. Encontra-se, portanto, implícito na ponderação, um argumento moral que define qual princípio teria prioridade sobre outro, o que serve de abertura para o exercício da discricionariedade judicial, camuflada pela moldura analítico-racional imposta à argumentação. A afirmação do caráter deontológico dos princípios é, porém, essencial para se construir um sistema de direitos não alterável pela simples definição discricionária do juiz, sob pena de se recair, circularmente, no arbítrio decisório. A teoria da argumentação jurídica torna-se, assim, justamente o que ela tentara evitar: um instrumento não de controle, mas de justificação do exercício do decisionismo judicial...

Quanto à objeção habermasiana segundo a qual o modelo da ponderação ensejaria a "queda do muro de fogo" de proteção aos direitos fundamentais, sustenta Alexy (2005b) que tais direitos possuem um "núcleo resistente" além do qual eles não podem ser atingidos. Trata-se do ponto no qual as intervenções não mais podem ser justificadas por meio de um reforço dos fundamentos da intervenção. Isso corresponde à chamada "lei da taxa marginal decrescente da subsunção", segundo a qual os "direitos fundamentais ganham sobreproporcionalmente em fortidão quando a intensidade das intervenções aumenta", o que lhes garante a manutenção de um núcleo essencial resistente (AlEXY, 2005b, p. 344).

Entretanto, cabe indagar: quem fixa tal "núcleo resistente"? Se cabe ao juiz efetuar a ponderação entre direitos, em que medida não se pode dizer que a fixação dos limites do núcleo dos direitos fundamentais dá-se segundo a subjetividade do julgador? E, se isso ocorre, qual seria a garantia contra a "queda do muro de fogo" dos direitos fundamentais?

Alexy (2005a) entende ser possível formular decisões racionais sobre conflitos entre princípios constitucionais. Trata-se de uma concepção de "racionalidade possível", que não se confunde com a racionalidade própria das ciências descritivas. A racionalidade possível da decisão fundamenta-se no fato de que esta se baseia em uma argumentação cujo valor pode ser colocado em discussão. A "fórmula de peso" não assegura objetividade plena nas decisões 
sobre princípios em conflito, visto que cada uma de suas variáveis deve ser preenchida pela argumentação. Entretanto, tal fórmula pretende demonstrar que o sopesamento não é fruto de decisões irracionais. Sua racionalidade reside, precisamente, na possibilidade de se argumentar racionalmente sobre as variáveis envolvidas na decisão, ou seja, na possibilidade de uma racionalidade discursiva.

Alexy (2005b) adverte, nesse sentido, que do fato de que não se poderia prescindir de valorações não se deve deduzir que, na medida em que essas são necessárias, haveria um campo livre para as convicções morais subjetivas dos aplicadores do Direito. Tal conclusão só seria válida, diz o autor, se não existisse em absoluto a possibilidade de objetivar tais valorações. Entende, ainda, que tal possibilidade de objetivação das decisões judiciais é medida pelo grau de cumprimento das condições comunicativas da argumentação que possibilitam um julgamento imparcial.

Mais uma vez, observa-se aqui um raciocínio circular: as decisões não são subjetivas porque podem ser objetivadas pelos critérios impostos pela teoria da argumentação, e estes existem e garantem a racionalidade das decisões porque as valorações a elas subjacentes podem ser objetivadas...

O mérito da tese de Alexy (2005a; 2008) reside, pois, precisamente naquilo que ela não consegue resolver, por tornar evidente aquilo sobre o que se deve discutir e onde estão as incertezas inelimináveis.

"Se há casos em que não é possível, em razão de limites da própria capacidade humana de discernir a única solução correta, nem mesmo a melhor entre várias, quando há mais de uma qualificável como correta, então não se pode considerar que 'tudo esteja contido nos princípios, nada restando a fazer senão concretizá-los através do sopesamento’. Aliás, é possível ir mais longe: a possibilidade de 'empate' como resultado do sopesamento é o que assegura todas as outras modalidades de competência normativa, diversas daquela exercida pelo Constituinte originário, nomeadamente a discricionariedade (administrativa e legislativa) e a autonomia privada" (GuERRA, 2006, p. 69).

Ao evidenciar, portanto, a existência da possibilidade de ser epistemicamente indeterminável qual princípio tem maior peso relativo no caso concreto, torna-se claro que é justamente tal possibilidade que atribui sentido à delimitação das competências entre Legislativo e Judiciário.

A seguir, analisaremos o modelo agonístico de democracia, proposto por Chantal Mouffe (2009), aplicando-o à tentativa de desconstrução da pretensão de legitimidade do método ponderativo, a fim de criticar o modelo de racionalidade que lhe serve de substrato e o atrelamento deste ao modelo de legi- 
timidade fundado na "representação argumentativa". Para tal, faremos breve incursão no pensamento de Ludwig Wittgenstein (1979), que serve de ponto de partida para o modelo da autora, e exporemos os pontos em que essa diverge e se aproxima da teoria discursiva habermasiana.

\subsection{A crítica de Chantal Mouffe}

\subsubsection{As investigações filosóficas de Wittgenstein}

A nova concepção wittgensteiniana presente nas Investigações filosóficas substitui, pela ideia de interação, a noção de representação do mundo por meio da linguagem. Segundo tal concepção, não se deve perquirir uma suposta essência oculta na linguagem, mas somente compreender seus diversos usos. Deve-se evitar uma atitude essencialista/semântica, e busca-se, pois, adotar uma postura pragmática.

Postula-se não haver uma linguagem universal, mas simplesmente uma variedade de usos compreendidos como jogos de linguagem, os quais possuem semelhanças em comum, como os membros de uma família. Os múltiplos jogos de linguagem constituem-se como formas de vida. O uso, nessa obra, relaciona-se com o conceito de significação:

"A significação de uma palavra é dada a partir do uso que dela fazemos em diferentes situações e contextos. (...) Com efeito, se a mesma expressão linguística for usada de outra forma ou em outro contexto, sua significação poderá ser outra, (...) dependendo do uso no novo contexto e das relações pragmático-linguísticas exigidas por ele" (CondÉ, 1998, p. 89).

A significação de uma expressão não se restringe, pois, a denominar objetos, mas compreende também sua operacionalização por meio de regras gramaticais. Aprender a significação de uma expressão assemelha-se a aprender um exercício determinado. É aprender a operar corretamente com uma expressão equivalente a tal significação (ConDÉ, 1998, p. 112). Cada mudança na regra, surgida da prática da linguagem, enseja, portanto, uma mudança de uso e de significação. De acordo com essa perspectiva pragmática, não é necessário haver correspondência entre palavras e objetos, na medida em que a significação não se limita exclusivamente à denominação destes e abrange a operação com expressões. Significações linguísticas são, portanto, fenômenos sociais. Elimina-se, assim, a dicotomia entre os fatos e a representação destes, visto que a linguagem passa a ser concebida como forma de interação no mundo e deixa de ser pensada como mero "espelho" dos estados de coisa (CONDÉ, 2004, p. 82). 
Destarte, por ser produto do uso, a significação não compreende uma essência invariável, mas modifica-se a cada uso feito da linguagem. Inexistem essências transcendentes e intermediárias em relação aos signos e aos fatos. Não cabe fazer perguntas metafísicas do tipo "o que é...?", mas apenas analisar como são usadas as expressões em diferentes contextos linguísticos. O jogo de linguagem envolve expressões e atividades às quais aquelas se interligam. Neste viés, "o sentido verdadeiro (enquanto algo fundamentado a priori, portador de uma essência) não existe, toda significação é constituída pela e na pragmática da linguagem (...)" (Condé, 2004, p. 27).

O uso processa-se de acordo com determinadas regras e, de outra parte, institui novas regras, as quais se encontram, pois, em fluxo contínuo. Elas regulam a dinâmica entre uso e contexto e compõem a gramática. As regras da gramática, por sua vez, relacionam-se com as formas de vida, de maneira que se pode dizer que a linguagem emerge destas. Nas palavras de Wittgenstein, "(...) representar uma linguagem significa representar-se uma forma de vida" (1979, p. 15, item 19).

Praticar um jogo de linguagem é, nesse sentido, parte de uma forma de vida. As regras são, pois, convenções surgidas da prática social e poderiam ser diferentes se tal prática fosse diversa. Elas são criadas pelo uso e, simultaneamente, são referências para tal uso. Assim, ao analisarmos os fatos, não estamos lidando com estes em si mesmos, mas com o emprego de uma palavra. Não se pode ter contato direto com os fatos, visto que nossa concepção acerca destes é feita a partir dos jogos de linguagem de uma determinada forma de vida e de uma gramática. A lógica, nesse sentido, constitui a própria gramática da linguagem, ou seja, expressa-se nas regras da gramática. Esta determina, pois, o que tem ou não sentido. O que faz sentido em uma gramática dada depende das convenções que constituem aquela gramática (CondÉ, 1998, p. 110). A gramática constrói, pois, os critérios a partir dos quais se elaboram nossos julgamentos.

Segundo Wittgenstein, “(..) depende inteiramente de nossa gramática o que é (logicamente) dito possível e o que não é (...)” (1979, p. 144, item 520). Em outro trecho, temos que "correto e falso é o que os homens dizem; e na linguagem os homens estão de acordo. Não é um acordo sobre as opiniões, mas sobre o modo de vida" (Wittgenstein, 1979, p. 94, item 241). Dessa forma, a lógica não é universal, visto que é intrínseca às linguagens, as quais são múltiplas e particulares. A lógica, portanto, emerge da gramática, advém do consenso, da praxis social comum, no uso de expressões em uma determinada forma de vida. "Em última instância, a linguagem repousa na 'forma de vida' ( $I$. F. 240), e não em uma categoria metafísica” (CondÉ, 1998, p. 125). 
Se os fatos fossem outros, outros seriam os jogos de linguagem. A noção de necessidade lógica é, nesse viés, apenas uma convenção formulada a partir de regras gramaticais que expressam um hábito no interior de uma forma de vida particular, e não uma essência metafísica e universal do mundo. Não é, pois, a partir do mundo que se constrói a linguagem, mas a partir desta constrói-se o mundo. Os mecanismos que regem a intelegibilidade dos fatos são pragmáticos. Isso significa que as instituições refletem formas de vida positivadas culturalmente, bem como que as regras são arbitrárias, no sentido de que são construídas a partir da praxis. O fundamento do conhecimento encontra-se na ação e não na essência transcendental ou empírica. A explicação de um fato não consiste em uma descoberta feita de um ponto de vista abstrato-transcendental, mas em uma criação, uma construção histórico-social. A linguagem, portanto, não espelha o mundo, mas o constrói.

\subsubsection{O modelo agonístico de Chantal Mouffe}

Chantal Mouffe (2009) critica o entendimento de autores, como Jürgen Habermas, que sustentam a possibilidade de um procedimento deliberativo, por meio do qual seria possível alcançar um consenso mais profundo do que um mero acordo sobre procedimentos para decidir (Mouffe, 2009, p. 83).

Como vimos, as concepções de Habermas (2001) e Alexy (2005a; 2008), apesar de suas divergências internas, convergem na busca comum de uma forma normativa de racionalidade. Isso se revela especialmente claro na obra de Habermas (2001), ao buscar estabelecer um vínculo entre valores liberais e democracia, refutando as críticas que proclamam a natureza contraditória da democracia liberal. As teses dos autores citados residem na premissa comum segundo a qual seria possível, por meio de procedimentos adequados de deliberação e decisão, alcançar formas de acordo que satisfaçam tanto a racionalidade (tomada como a defesa de direitos liberais) quanto a legitimidade democrática (representada pela soberania popular). Esse entendimento, como já analisado acima, consiste em reformular o princípio democrático da soberania popular, de modo a eliminar os perigos que ele impõe aos valores liberais. Para tal, a soberania popular é reinterpretada em termos intersubjetivos e redefinida como poder comunicativo (MoufFe, 2009, p. 83-84).

Habermas (2001), de sua parte, crê em uma forma de racionalidade que não é apenas instrumental, mas possui uma dimensão normativa: a razão comunicativa, fundada na troca de argumentos entre pessoas razoáveis guiadas pelo princípio da imparcialidade. Nessa perspectiva, a base de legitimidade das instituições democráticas resultaria do fato de que as decisões tomadas pelas ins- 
tâncias que possuem poder de obrigar representam, ainda que potencialmente, um ponto de vista imparcial que atua igualmente no interesse de todos. Para Habermas (2001), a razoabilidade da decisão resultante do processo deliberativo é garantida desde que tal procedimento realize a condição ideal do discurso: quanto mais igualitário e imparcial, tanto mais aberto será o procedimento, e maior será a possibilidade de os partícipes do discurso serem guiados pela força do melhor argumento. Nenhum limite substancial é imposto, pois, ao conteúdo da deliberação. Apenas os limites procedimentais da situação ideal de discurso eliminam as posições com as quais os participantes do discurso não podem concordar. Reconhece-se que há obstáculos à realização da situação ideal de discurso, mas esses são considerados meramente empíricos (Mouffe, 2009, p. 85-87).

Como vimos, Habermas (2001) parte de um conceito amplo de razão, a partir do qual sustenta a tese de que as questões práticas podem ser decididas racionalmente, por meio da força do melhor argumento. As questões práticas são suscetíveis de verdade em sentido amplo, fixado no bojo de uma teoria consensual de verdade, que se contrapõe à teoria da verdade como correspondência entre enunciados e fatos. Na concepção consensual de Habermas (2001), a condição de verdade de um enunciado é o assentimento potencial de todos os partícipes do discurso. A correção das normas depende, em última instância, de que se possa alcançar o consenso em uma situação de total liberdade e simetria entre os partícipes do discurso: a situação ideal de fala ou de diálogo. Nesse contexto, a validade da norma reside no assentimento de todos os partícipes do discurso, obtido por meio de um procedimento em que são garantidas a autonomia e a igualdade entre tais participantes.

$\mathrm{Na}$ visão de Habermas (2001) e Alexy (2005a; 2008), questões políticas fundamentais podem ser decididas racionalmente, e a validade de tal decisão advém de uma fonte independente que possui, ainda que potencialmente, alcance universal. A troca de argumentos seria, assim, o procedimento mais adequado para se alcançar a formação racional da vontade, da qual emergiria o interesse geral. Desde que assegurem imparcialidade, igualdade, abertura e ausência de coerção, os procedimentos de deliberação e decisão seriam capazes de guiar o debate em direção a interesses generalizáveis sobre os quais os partícipes do discurso poderiam concordar, o que conduziria a resultados legítimos.

Assim, na visão de Mouffe (2009), teses como as de tais autores fundamentam a adesão à legitimidade da decisão em um tipo de consenso racional que precluiria a possibilidade de contestação, desde que obedecidos procedimentos capazes de levar a resultados racionais por meio da participação democrática e da argumentação livre e igual (Mouffe, 2009, p. 88-89). Chantal Mouffe 
(2009), de sua parte, discorda da premissa segundo a qual seria possível um consenso racional sobre questões políticas como resultado de um debate livre entre iguais. A autora sublinha, pois, a impossibilidade de se circunscrever um espaço que não esteja submetido ao pluralismo de valores, e no qual um consenso sem exclusão possa ser estabelecido. Para ela, o domínio da política não é um terreno neutro que poderia ser insulado do pluralismo de valores, e no qual soluções racionais e universais poderiam ser formuladas. Segundo Mouffe (2009), a teoria discursiva afasta a política das consequências mesmas do pluralismo de valores, ao relegar tal pluralismo a um espaço não público (Mouffe, 2009, p. 92).

Aqui gostaríamos de objetar, à crítica da autora, que, em nosso entender, a teoria discursiva não releva o pluralismo ao espaço não público, mas sim trabalha-o no espaço público - neutralizando-o, porém, por meio da ideia de consenso. Mouffe (2009) argumenta que a tese de Habermas (2001), segundo a qual democracia e direitos individuais seriam cooriginários, acaba por negar a natureza paradoxal da democracia e a tensão fundamental entre a lógica da democracia e a do liberalismo. Para a autora, tal tensão pode ser negociada de diferentes maneiras, por meio da articulação de soluções precárias. Entretanto, uma solução final racional é inviável, e a tentativa de alcançá-la coloca limites ao próprio debate político. É, pois, necessário reconhecer o pluralismo de valores que a democracia compreende, bem como reconhecer a natureza política dos limites impostos ao debate, ao invés de serem apresentados como requisitos da moralidade ou da racionalidade do discurso (Moufre, 2009, p. 93-94).

A autora postula que, ao privilegiar a racionalidade, as teses como a de Habermas (2001) e Alexy (2005a; 2008) deixam de lado um elemento central: o papel exercido pelas paixões e afetos para se assegurar fidelidade aos valores democráticos. O indivíduo é abstraído das relações sociais e de poder, da linguagem, da cultura e do conjunto total de práticas em que está inserido de sua gramática, portanto. Diferentemente, a legitimidade das decisões, para Mouffe (2009), somente é possível pela multiplicação de instituições, de discursos e de formas de vida que estimulem a identificação com valores democráticos, e não por meio de argumentos acerca da racionalidade supostamente incorporada nas instituições democráticas (Mouffe, 2009, p. 95-96). Nesse ponto específico, gostaríamos de novamente objetar à crítica da autora, porquanto tanto no modelo agonístico, quanto no habermasiano, postula-se uma expansão de canais institucionais para expressão de conflitos.

A fim de solucionar o paradoxo entre liberalismo e democracia, Mouffe (2009) sugere que esse seja tomado sob uma perspectiva diferente: a ênfase deve ser colocada nos tipos de práticas e não nas formas de argumentação. 
A fim de que se obtenha consenso quanto a argumentos, necessário se faz o consenso quanto a formas de vida. Na esteira de Wittgenstein (1979), Mouffe (2009) argumenta que procedimentos apenas são aceitos porque estão inscritos em formas compartilhadas de vida e em acordos quanto a juízos, e não devem ser tomados como regras criadas com base em princípios e aplicadas a casos específicos. Nesse sentido, uma separação estrita entre os âmbitos substancial e procedimental não se mantém. Procedimentos sempre envolvem compromissos éticos substanciais e nunca são, pois, puramente neutros (MoufFe, 2009, p. 96-97).

A legitimidade de uma decisão independe, portanto, de que a ela se dê um fundamento puramente intelectual. Diferentemente, tal legitimidade reside em um compromisso apaixonado a um sistema de referência: é uma forma de vida compartilhada. Isso implica, ainda, reconhecer os limites de um consenso. Assim, "levar o pluralismo a sério" implica desistirmos do sonho de um consenso racional que compreende a fantasia de que possamos escapar de nossa forma de vida: "We've got on to slippery ice where there is no friction and so in a certain sense the conditions are ideal, but also, just because of that, we are unable to walk: so we need friction. Back to the rough ground"7 (Wittgenstein, 1958, p. 46e).

Isso significa que, longe de serem meramente empíricos, os obstáculos enfrentados pela situação ideal do discurso são ontológicos, pois as formas de vida que são vistas como seu impedimento são sua própria condição de possibilidade (Mouffe, 2009, p. 98). Dessa maneira, o modelo agonístico, além de colocar a ênfase em práticas e em jogos de linguagem, requer que se reconheça que o poder é constitutivo das relações sociais. Para a autora, Habermas (2001) e Alexy (2005a; 2008), ao postularem um esfera em que o poder teria sido eliminado e só restaria a força do melhor argumento, ou a autoridade da decisão razoável e proporcional, deixam de reconhecer a dimensão de antagonismo inerente ao pluralismo de valores, a qual é impossível de ser erradicada.

A questão do poder e do antagonismo deve ser, portanto, colocada no centro da discussão acerca da legitimidade da decisão em casos de conflito entre princípios. Qualquer decisão, por ser constituída por meio de atos de poder, é política - e deve, pois, revelar os traços de exclusão que governam sua consti-

7. "Nós chegamos ao gelo escorregadio, onde não há qualquer fricção e, então, em certo sentido, as condições são ideais, mas, precisamente por isso, somos incapazes de caminhar: então, precisamos de fricção. Retornemos ao chão áspero" (trad. livre da autora). 
tuição. O poder é, então, concebido não como uma relação externa entre duas identidades pré-constituídas, mas sim como algo que constitui tais identidades.

Como qualquer ordem política é expressão de hegemonia (ou seja, de um padrão específico de relações de poder), a prática política não pode ser vista como representativa de interesses de identidades pré-constituídas, mas sim como constituindo tais identidades em terrenos precários e vulneráveis (MoufFe, 2009, p. 99-100). Assim, se relações de poder são constituintes das relações sociais, a questão quanto à legitimidade das decisões não reside na eliminação ou na racionalização do poder e da violência, mas na abertura para a constituição permanente de novas formas de poder. Deve ser abandonado o ideal de uma harmonia perfeita e transparente, na medida em que a legitimidade de uma decisão apenas pode residir no fato de que nenhum ator social pode atribuir a si a representação da totalidade e reclamar a si a fundação desta.

Nesse sentido, se um poder foi capaz de se impor, isso se dá porque foi capaz de ser reconhecido como legítimo em alguns âmbitos. Essa legitimidade não se baseia, porém, em um fundamento apriorístico, mas sim em uma forma bem sucedida de poder. Tal fato, porém, segundo Mouffe, é obscurecido pelas teses de Habermas (2001) e Alexy (2005a; 2008), das quais o poder foi eliminado e nas quais a legitimidade é fundada puramente em uma forma de racionalidade (Mouffe, 2009, p. 100-101).

A autora distingue, nessa esteira, entre as esferas do "político" e da "política". "O político" refere-se à dimensão de antagonismo inerente às relações humanas. "A política", por sua vez, indica o conjunto de práticas, discursos e instituições que buscam estabelecer certa ordem e organizar a coexistência humana em condições potencialmente conflituosas, por serem afetadas pela dimensão do político. Somente ao se reconhecer a dimensão "do político", e ao se entender que "a política" consiste em domesticar hostilidades, é que podemos nos indagar como criar uma unidade precária em um contexto de conflito e diversidade - ou seja, como criar um "nós" por meio da determinação de um "eles". Nunca devemos indagar, portanto, como alcançar o consenso, pois isso implicaria a erradicação do político. Não se deve superar essa oposição "nós/ eles", mas sim estabelecê-la permanentemente de maneiras diversas (Mouffe, 2009, p. 100-101).

O objetivo do modelo agonístico é, pois, construir esse âmbito do "eles" de forma tal que ele não mais seja percebido como um inimigo a ser destruído, mas como um adversário, alguém cujas ideias combatemos, mas cujo direito a defendê-las nós não questionamos. A categoria do adversário não elimina o antagonista, mas o toma como um inimigo legítimo, com quem partilhamos um 
terreno comum, porque temos uma adesão compartilhada a princípios ético-políticos da democracia liberal: a liberdade e a igualdade. Em caso de desacordo quanto à forma de implementação de tais princípios, tal desacordo não pode ser resolvido por meio de deliberação ou argumentação racional. Não há solução racional para o conflito, daí sua natureza agonística. Isso requer, pois, que sejam providos canais através dos quais sejam dados às paixões coletivas modos de se expressarem como adversárias, não como inimigas. Não se devem eliminar da esfera pública as paixões com o objetivo de se atingir um consenso racional, mas sim mobilizá-las rumo a desenhos democráticos. A democracia e a legitimidade residem, portanto, no reconhecimento do conflito e na recusa de suprimi-lo por meio de uma autoridade racional (Mouffe, 2009, p. 102-103).

"It is for that reason that the ideal of a pluralistic democracy cannot be to reach a rational consensus in the public sphere. Such a consensus cannot exist. We have to accept that every consensus exists as a temporary result of a provisional hegemony, as a stabilization of power, and that it always entails some form of exclusion. The ideas that power could be dissolved through a rational debate and that legitimacy could be based on pure rationality are illusions which can endanger democratic institutions"8 (Mouffe, 2009, p. 104).

A autora não nega que a democracia pluralista demanda certa medida de consenso e que esse requer fidelidade aos valores que constituem seus princípios político-éticos. Mas, como tais princípios somente existem por meio de diferentes e conflituosas interpretações, tal consenso, segundo Mouffe (2009), está fadado a ser sempre conflituoso.

\subsubsection{Aplicação do modelo agonístico de democracia aos problemas da legitimidade e da decidibilidade em caso de conflitos entre princípios}

Como vimos, na visão de Alexy (2005a), a legitimidade das decisões residiria na racionalidade do procedimento pelo qual são tomadas, que garantiria que fossem alcançadas a partir de um ponto de vista imparcial, com fundamento em uma "representação argumentativa". Alexy (2005a) parte, assim, da

8. "É por essa razão que o ideal de uma democracia pluralista não pode ser alcançar um consenso racional na esfera pública. Um tal consenso não pode existir. Temos que aceitar que cada consenso existe como um resultado temporário de uma hegemonia provisória, como a estabilização do poder, e que isso sempre compreende uma forma de exclusão. As ideias segundo as quais o poder pode ser dissolvido por meio de um debate racional e segundo as quais a legitimidade poderia ser baseada em racionalidade pura são ilusões que podem colocar em perigo as instituições democráticas" (trad. livre da autora). 
premissa segundo a qual um método analiticamente estruturado, que trabalha argumentos em fundamentos lógicos, pode controlar racionalmente e garantir a correção e a legitimidade de uma interpretação jurídica.

Questiona-se, pois, com base no pensamento de Chantal Mouffe (2009): (a) a moldura analítica formada pela teoria da argumentação jurídica, ao se colocar fora do próprio conteúdo a ser objeto da deliberação, pode assegurar a legitimidade da negociação contínua entre constitucionalismo e democracia, poder e lei, direito e política?; e (b) tal moldura atuaria como canal de expressão de um conflito real de interesses, ou como mera camuflagem que busca negar a existência deste?

Por meio da aplicação do modelo agonístico, é forçoso reconhecer que toda decisão compreende um momento de força e violência que nunca pode ser eliminado. Alexy (2005a; 2008), porém, apenas contorna a natureza parcial hegemônica de todo consenso, e delineia procedimentos argumentativos que implicam a possibilidade de pluralismo sem antagonismo. A noção de alteridade, porém, é irredutível a qualquer forma de consenso. A indecidibilidade ínsita a toda argumentação jurídica não é, pois, um fator a ser superado: a decisão em favor de uma alternativa é sempre tomada em detrimento de outra. Todo consenso e toda decisão é a estabilização de algo essencialmente instável. A busca de uma estabilidade contínua significaria o fim da política, e o fim da possibilidade de legitimação de qualquer decisão. O que fazer com essa violência e como lidar com o antagonismo são questões para as quais nunca há uma solução final, redutível a um simples cálculo racional.

Os interesses individuais e o interesse público, os direitos subjetivos e coletivos são, nesse sentido, irreconciliáveis. Na democracia liberal, sempre se impõem limites ao exercício da soberania pelo povo. Tais limites são apresentados, usualmente, como responsáveis por fornecer a moldura para o respeito dos direitos humanos e como sendo não negociáveis. Para Chantal Mouffe (2009), diferentemente, como dependem da forma como os direitos humanos são interpretados em determinado momento, tais limites são a expressão de uma hegemonia e são, pois, sempre contestáveis.

A democracia liberal resulta, pois, da articulação de duas lógicas incompatíveis e irreconciliáveis. A tensão entre elas somente pode ser estabilizada temporariamente, por meio de negociações entre forças políticas, negociações essas que sempre estabelecem a hegemonia de uma dessas forças. Só pode haver formas contingentes de estabilização do conflito entre igualdade e liberdade. Se desaparece a alternativa para a configuração de poder existente, desaparece também a possibilidade mesma de uma forma legítima de expressão para a resistência contra as relações de poder dominantes: há uma naturalização do status quo. 
A ponderação de princípios, nos moldes propostos por Alexy (2005a; 2008), neutraliza a confrontação agonística e permanente entre diferentes interpretações possíveis (e irredutíveis entre si) em caso de colisão. A ideia de uma harmonização de interesses, por meio da otimização de um princípio e da preservação da essência do outro princípio colidente em determinado caso, camufla a existência de um antagonismo, mas não o elimina. Diferentemente, tal ideia camufla o fato de que, em realidade, por meio de uma decisão supostamente ponderativa, há apenas a imposição de um princípio em detrimento do outro, em sua totalidade, hegemonicamente. Princípios não são ponderados: ponderam-se razões fáticas e jurídicas para a escolha de um princípio. Não se otimizam princípios: escolhe-se entre um princípio e outro, aplicando um deles integralmente. A teoria da argumentação jurídica camufla, portanto, tal decisão hegemônica, por meio de um método de fornecimento de razões que justificaria a correção de tal decisão e lhe serviria de fonte de legitimidade.

Todo consenso e toda decisão baseiam-se, porém, em uma forma de exclusão. Ao invés de tentar apagar os traços de poder e exclusão deixados por uma decisão, uma teoria da argumentação deveria trazê-los à luz, de modo que possam ser contestados, a fim de que não seja eliminada a indecidibilidade ínsita do ato de decidir, que é a condição de possibilidade de toda decisão.

"To imagine that pluralist democracy could ever be perfectly instantiated is to transform it into a self-refuting ideal, since the condition of possibility of a pluralist democracy is at the same time the condition of impossibility of its perfect implementation. Hence the importance of acknowledging its paradoxical nature"9 (MoufFe, 2009, p. 16).

Questiona-se, ainda, se o catálogo de direitos fundamentais constituiria de fato uma sistema objetivo e hierarquizado de valores. Valores são tiranos, como observava Carl Schmitt, pois reivindicam uma vigência absoluta que implica a negação de valores opostos (Dimoulis; Martins, 2011, p. 261). Uma tal ordem "objetiva de valores", de fato, inexiste. A Constituição não estabelece uma classificação hierarquizada entre os direitos fundamentais, e não indica antecipadamente qual dos direitos prevaleceria em relação aos demais, em casos de colisão. A escolha entre um direito ou outro é sempre política. Todos os

9. "Imaginar que a democracia poderia ser perfeitamente realizada é transformá-la em um ideal autorrefutável, uma vez que a condição de possibilidade de uma democracia pluralista é, ao mesmo tempo, a condição de impossibilidade de sua implementação perfeita. Daí a importância de reconhecer sua natureza paradoxal" (trad. livre da autora). 
direitos fundamentais possuem a mesma dignidade normativo-constitucional, de modo que qualquer hierarquização concreta entre eles possui caráter político (Dimoulis; Martins, 2011, p. 210-211). O fato de uma decisão basear-se em um procedimento argumentativo não elimina, portanto, seu caráter político.

O modelo argumentativo proposto por Alexy (2005a) renega a dimensão de indecidibilidade e o caráter não erradicável do antagonismo, os quais são constitutivos do político. Nos moldes previstos pelo modelo agonístico, o término uma deliberação resulta sempre de uma decisão que exclui outras possibilidades, e pela qual ninguém deveria recusar assumir responsabilidade invocando os comandos de princípios ou a racionalidade de determinada argumentação. É vital abrir espaço para o dissenso, e superar a tendência de uma decisão jurídica naturalizar suas fronteiras e essencializar suas identidades.

A proporcionalidade constitui-se, pois, como uma busca perdida por precisão e objetividade para a solução dos conflitos entre princípios, uma vez que encobre as questões morais e políticas reais que são o substrato de tais disputas. As Cortes constitucionais deveriam, portanto, ter como foco a discussão direta das disputas políticas e morais implícitas nos conflitos entre princípios. É necessário que democracia não seja confundida com constitucionalismo, ou que a política seja subsumida ao direito, e vice-versa. É necessário que um seja permanente passível de ser reinventado pelo outro. Considerando que qualquer lei ou decisão, como expressão de poder, pratica violência (visto que nunca pode render justiça inteiramente ou alcançar a harmonia perfeita em caso de conflito), indaga-se: como uma decisão pode ser legítima? No modelo agonístico, legitimidade e violência estão em uma relação de permanente tensão. Não há decisão sem o risco do fracasso de trazer injustiça e essa é, paradoxalmente, a condição mesma de possibilidade da justiça.

Quando a tomada de decisão utiliza-se de um procedimento analítico racional como logos justificante, tal decisão encobre um conflito - e comete uma injustiça. A presença de um logos como guia do processo de tomada de decisão elimina, implicitamente, o direito de se criticar publicamente o próprio procedimento de decisão, que não é colocado em jogo, por ser tido como racional. Tal procedimento transforma-se, pois, em um discurso de reprodução de uma identidade.

A defesa da ponderação não é seguida pelo ato de se colocar tal método em negociação. A correção, enquanto referida a uma estrutura racional, torna-se, assim, um monólogo. Um juiz, desde que simplesmente aplique essa moldura estrutural, detém a liberdade de definir se um argumento é correto ou não, bom ou mal, e em que medida. Por detrás do caráter argumentativo da pretensão de correção, há standards morais que se naturalizam: é a consciência do 
juiz que acaba por definir quem é o povo e quais são os valores que esse povo aceitaria, e como os balancearia. O juiz define quem justifica a decisão e o que pode ser justificado. A fim de sustentar sua racionalidade, tal modelo precisa submeter os conflitos a uma identidade. Essa é sua condição mesma de racionalidade.

Os critérios de correção não passam, pois, de critérios para a camuflagem da discricionariedade judicial. Ao final, a relevância de um princípio sobre o outro e o modo como são definidas as condições de prioridade são definidos discricionariamente, e podem ser o fundamento de qualquer resultado. Tal resultado varia apenas de acordo com os standards morais de que parte o julgador, e não de acordo com a moldura racional do processo argumentativo que serviu de base à decisão.

Cada caso é sempre singular, e não há método ou padrão que possa reduzi-lo sem o risco de privilegiar a democracia ou o constitucionalismo, a política ou a lei, um interesse ou outro. Se o uso de critérios racionais pretende servir de fundamento à tomada de decisões, precisa ser colocado em jogo: precisa ser reconstruído. A redução das particularidades de um caso, por meio de um método, é sempre um momento inevitável de violência, que busca seu fundamento em critérios e argumentos manejados de acordo com a consciência do juiz.

Como visto, para Alexy (2005a), a argumentação jurídica é entendida como um caso especial da argumentação prática geral. Sua peculiaridade reside apenas nos vínculos institucionais que a caracterizam (a lei, o precedente, a doutrina). Na medida em que tais vínculos são insuficientes para levar a um resultado preciso, as regras do discurso atuam para que se conte com um mínimo de racionalidade, mas não para que se obtenha uma única resposta correta. Para Alexy (2005a), portanto, a questão da resposta correta resume-se no desenvolvimento de um procedimento que conduza a uma decisão racional.

Dilui-se, pois, a pretensão de correção da teoria da argumentação jurídica, na medida em que a racionalidade da metodologia adotada pelo julgador é insuficiente para atribuir neutralidade à decisão: esta é sempre a tomada de posição em favor de um interesse e da eliminação de outro. Ademais, com substrato no pensamento de Wittgenstein (1979), infere-se que a racionalidade de um procedimento não reside em uma determinada metodologia supostamente apta a controlar os dados empíricos e orientar a tomada de decisão, mas sim em uma determinada forma de vida compartilhada. Procedimentos apenas são aceitos porque estão inscritos em formas compartilhadas de vida e em acordos provisórios quanto a juízos.

A relativização do caráter deontológico dos princípios faz emergir, ainda, o risco de se transmutar a tomada de decisão em mera reprodução de um discur- 
so moralizador, em detrimento de minorias. Nesse ponto, a questão quanto à legitimidade de uma decisão faz-se sentir de forma clara: quem tem a última palavra quando estão em jogo direitos fundamentais conflitantes? Observe-se que tanto o Judiciário quanto o Legislativo precisam representar o povo por meio, respectivamente, da decisão sobre casos e pela elaboração de leis. Como uma instituição recebe autoridade para atuar em nome da sociedade?

Como vimos, Alexy (2005a; 2008) defende a legitimidade das cortes constitucionais com base na ideia de "representação argumentativa". Diferentemente do Poder Legislativo, que seria, para o autor, decisional e argumentativo, as Cortes representariam o povo de uma maneira puramente argumentativa, desde que: (a) existam argumentos corretos; (b) existam pessoas racionais, capazes de aceitar tais argumentos por serem corretos. Desde que as cortes institucionalizem o discurso e sigam essas condições, suas decisões alcançariam legitimidade.

Diferentemente, a legitimidade das decisões, para Mouffe (2009), somente é possível por meio da multiplicação de instituições, de discursos e de formas de vida que estimulem a identificação com valores democráticos, e não por meio de argumentos acerca da racionalidade supostamente incorporada nas instituições democráticas. O caráter discursivo da argumentação representativa não passa, assim, de um monólogo da Corte: a definição do fórum ao qual se dirige e dos valores levados ao balanceamento são controlados apenas pela Corte, que decide em última instância. Indaga-se, assim: uma tal representação argumentativa de fato representa o povo, ou usa de seu caráter argumentativo para camuflar a discricionariedade de uma decisão fundada em standards valorativos?

Recorde-se que, nos moldes da teoria da argumentação jurídica, na decisão jurisdicional, diferentemente da decisão legislativa, princípios constitucionais são balanceados a partir de standards morais, sem que seja estabelecida a garantia de regras antimajoritárias, as quais são introduzidas a fim de preservar a voz das minorias representadas no Parlamento. Tais decisões políticas são tomadas, ainda, sem o controle exercido por eleições periódicas. Nesses termos, a pretensão de legitimidade das decisões judiciais, ao vincular a decisão às aspirações da sociedade, legitima o uso da força como meio de satisfazer a voz da maioria, ensejando a imposição do princípio democrático sem as garantias do constitucionalismo. Por outro lado, o uso da lei contra a voz da maioria enfatiza tais garantias em detrimento da força legitimadora da democracia. Para Chantal (2009), democracia e constitucionalismo estão, pois, em estado de tensão permanente. Em Alexy (2005a; 2008), ao contrário, a deontologia dos princípios é distorcida e flexibilizada em favor de um entendimento teleoló- 
gico, a fim de que a decisão satisfaça à vontade coletiva, na qual residiria sua legitimidade.

Trata-se, portanto, de uma postura de autoritarismo implícito, porquanto a manutenção do caráter deontológico da lei é um requisito para a preservação mesma da democracia. O princípio democrático e sua tensão com o constitucionalismo não se reduzem à argumentação representativa. Na teoria da argumentação, as cortes constitucionais tornam-se a instância suprema dos ideais da sociedade, a voz de uma ordem concreta de valores. Entretanto, devemos indagar: o papel que delas esperamos é de fato (e tão somente) a defesa de ideais coletivos?

No que concerne à proporcionalidade, cabe pontuar que a metáfora representada pela ponderação como balança sugere precisão, na medida em que sugere que, ao medirmos diferentes bens, nossas decisões teriam uma precisão métrica. A escala de valores, como símbolo da justiça, expressa a antiga e conhecida tentativa de se investir os julgamentos judiciais com a precisão das ciências naturais. Não resta claro, porém, o que é pesado (interesses, princípios, direitos), como é pesado (com qual métrica) e quem faz a ponderação (ou quem deveria fazê-lo: juízes ou legisladores).

A ponderação nada nos diz sobre o modo pelo qual interesses públicos e privados podem ser comparados, e tal silêncio reflete a impossibilidade de se medir valores incomensuráveis por meio de uma métrica quantitativa. A ponderação sugere que todos os interesses tuteláveis seriam, em última instância, redutíveis a uma métrica comum e, uma vez traduzidos para tal escala, poderiam ser medidos um em face do outro. Tal método perde, assim, muito de sua motivação teorética: de fato, a ponderação faz sentido apenas no caso de conflito entre valores. Se todos os valores são redutíveis a uma métrica comum, o problema que deu razão à necessidade do método ponderativo se dissolve. Corre-se o risco de tentar comparar laranjas e maçãs...

Isso não significa, porém, que valores seriam incomensuráveis no sentido de que nunca poderíamos decidir racionalmente entre eles, ou que nunca teríamos fundamentos racionais para preferir uns a outros. Entretanto, a possibilidade de um fundamento racional é insuficiente para conferir legitimidade à decisão. Diferentemente, em favor de uma "incomensurabilidade fraca", que reconhece a falta de uma métrica comum para a ponderação, permite-se que valores sejam colocados em relação uns com os outros. Essa relação não é, porém, quantitativa. O princípio da proporcionalidade assume que os conflitos entre valores poderiam ser reduzidos a questões de intensidade e grau, e que tal intensidade poderia ser medida por meio de uma escala comum. Pretende, assim, ser objetivo, neutro e totalmente estranho a qualquer discussão política. 
A adoção da ponderação no âmbito do princípio da proporcionalidade traz o risco de se negligenciar a complexidade da valoração política e a complexidade dos direitos. São negligenciados o fato de que nosso universo moral e político inclui ideias não quantificáveis, irredutíveis, não passíveis de harmonização. Passa-se a impressão de que a ponderação supera o desacordo sem nada negar, ao se entender que interferências proporcionais em um direito não seriam negativas, mas simplesmente acomodariam um interesse público, identificado com o interesse da maioria.

A ponderação é um método estruturado de decisão que não imiscui juízes em questões políticas profundas em toda sua complexidade e contestabilidade - e os imuniza quanto aos consequentes problemas de legitimidade. Teme-se o desacordo, e tenta-se ultrapassá-lo mascarando-se a argumentação em um método neutro.

A própria ideia de que os direitos possuiriam um cerne que não deve ser comprometido implica um juízo moral substantivo sobre o que é certo e errado. Isso leva, porém, à completa erosão da própria ideia dos direitos humanos, e negligencia o fato de que tais direitos não são apenas meras quantidades de liberdade, mas sim tutelam status básicos dos indivíduos. A discussão acerca dos conceitos de "judicialização da política" ou de "ativismo judicial" tem como pano de fundo uma teoria normativa da Política e do Direito fundada em uma concepção bastante particular da separação de Poderes em um Estado de Direito. Nesse viés, "judicialização da política" e "ativismo judicial" são os lados de uma mesma moeda, vista ora da perspectiva da política que seria "invadida" pela lógica judicial, ora da perspectiva do próprio direito "invasor".

A tentativa de legitimação de uma decisão judicial por meio do conceito de "representação argumentativa" funda-se em uma visão: (a) do Legislativo como o centro vivo de um Estado Democrático de Direito, a sede por excelência da política; (b) do Judiciário como centro vivo do constitucionalismo e da aplicação técnica da lei, infenso à política, ao o conflito social e aos debates na esfera política. Entretanto, a tensão entre Lei e Política, constitucionalismo e democracia não pode ser bipartida entre órgãos, porquanto está presente em todos os momentos de decisão, tanto judicial quanto legislativa. Desconsiderar tal realidade significa conservar e naturalizar uma determinada distribuição de poder entre grupos e uma determinada forma de mediar a relação entre Estado e sociedade. $\mathrm{O}$ mero ato de apresentar a racionalidade do suposto "jogo decisório" já é um ato interessado e precisa ser posto em evidência.

Uma concepção tradicional do Direito como a que sustenta as ideias de "judicialização da política" e de "ativismo judicial" veda o acesso a esses processos simultâneos de tradução e de exclusão próprios da juridificação. Mais 
que isso, essa concepção congela o Direito e seu código de tal maneira que a própria possibilidade de pensar a regulação jurídica de conflitos sob novas formas sociais, legais e institucionais desaparece do horizonte dos atores (Nobre; Rodriguez, 2011, p. 17).

Assim, deve-se assinalar que o próprio processo de interpretação e de efetivação da Constituição é um processo político cujo resultado não está predeterminado pelo texto mesmo e não é passível de ser legitimado pela simples adoção de um procedimento prévio de argumentação.

A partir dessas considerações, acreditamos que se torna possível recolocar o problema de fundo envolvido nas ideias de "judicialização da política" e de "ativismo judicial" em novos termos. Deixando de lado o normativismo presente nessas noções, o que surge diante dos olhos é um processo de desenvolvimento das instituições democráticas que ainda vai encontrar, nos conflitos sociais e políticos em curso, respostas para questões como separação de poderes, funcionamento interno do Judiciário, ou mesmo o que virá a ser compreendido como "direito" e "direitos" (Nobre; Rodriguez, 2011, p. 19).

Pensar o problema do ativismo judicial nos moldes fornecidos pela teoria da argumentação de Alexy (2005a) é, portanto, enquadrar a relação entre Política e Direito nos velhos moldes fornecidos pelo normativismo. Necessário se faz, entretanto, repensar tal relação em novos moldes.

\section{CONSIDERAÇÕES FINAIS}

A Teoria da Argumentação Jurídica de Alexy (2005a), como método decisório, baseia-se, como vimos, na premissa não questionada segundo a qual a ponderação seria o resultado natural da diferenciação entre regras e princípios. Parte-se, assim, da premissa de que os princípios teriam um caráter de mandamentos de otimização, o que implicaria o princípio da proporcionalidade, e vice-versa. Princípios seriam equiparados a valores, e por isso seriam otimizáveis, e vice-versa. Tal premissa conduz, portanto, à conclusão irrecorrível de que a ponderação seria inevitável. Não se discute por que princípios deveriam ser concebidos dessa maneira, ou por que eles possuiriam esse atributo teleológico de serem realizados na maior medida possível.

Uma concepção axiológica das normas não apresenta, porém, o potencial de universalização contido nos discursos sobre a correção das normas, uma vez que está enraizada em preferências. Tal concepção conduz, pois, a uma colonização do mundo da vida pelo Poder Judiciário, com a expansão da racionalidade instrumental, desalojando a racionalidade comunicativa e gerando uma crise de legitimidade do direito. Deixa-se de falar em adequabilidade, e 
passa-se a falar em preferibilidade, de modo que os princípios não mais indicam o que é devido, mas o que é preferível, e corre-se o risco de se confundir direitos com bens que podem ter sua aplicação negociada conforme as preferências da autoridade que decide.

A legitimidade de uma decisão independe, portanto, de que a ela se dê um fundamento puramente intelectual. Diferentemente, tal legitimidade reside em um compromisso apaixonado a um sistema de referência: é uma forma de vida compartilhada. Isso implica, ainda, reconhecer os limites do consenso. Ao se postular uma esfera em que o poder teria sido eliminado e só restaria a força do melhor argumento, ou a autoridade da decisão razoável e proporcional, deixa-se de reconhecer a dimensão de antagonismo inerente ao pluralismo de valores, a qual é impossível de ser erradicada.

A ponderação de princípios, nos moldes propostos por Alexy (2005a; 2008), neutraliza a confrontação agonística e permanente entre diferentes interpretações possíveis (e irredutíveis entre si) em caso de colisão. A ideia de uma harmonização de interesses, por meio da otimização de um princípio e da preservação da essência do outro princípio colidente em determinado caso, camufla a existência de um antagonismo, mas não o elimina. Tal ideia camufla, portanto, o fato de que, em realidade, por meio de uma decisão supostamente ponderativa, há apenas a imposição de um princípio em detrimento do outro, em sua totalidade, hegemonicamente. Princípios não são ponderados: ponderam-se razões fáticas e jurídicas para a escolha de um princípio. Não se otimizam princípios: escolhe-se entre um princípio e outro, aplicando um deles integralmente. A Teoria da Argumentação Jurídica camufla, portanto, tal decisão hegemônica, por meio de um método de fornecimento de razões que justificaria a correção de tal decisão e lhe serviria de fonte de legitimidade.

A tentativa de legitimação de uma decisão judicial por meio do conceito de "representação argumentativa" funda-se em uma visão: (a) do Legislativo como o centro vivo de um Estado Democrático de Direito, a sede por excelência da política; (b) do Judiciário como centro vivo do constitucionalismo e da aplicação técnica da lei, infenso à política, ao o conflito social e aos debates na esfera política. O problema, portanto, não reside no controle metodológico da subjetividade dos julgadores (cuja decisão sempre terá elementos não passíveis de consenso e de controle intersubjetivo, mormente considerando-se que a aplicação de normas sempre dá azo a uma certa medida de discricionariedade), mas na detecção de canais institucionais para que se expressem os diferentes interesses em conflito, bem como na análise da autoridade legítima para a tomada da decisão discricionária.

Recorde-se que, nos moldes da Teoria da Argumentação Jurídica, na decisão jurisdicional, diferentemente da decisão legislativa, princípios constitucionais 
são balanceados a partir de standards morais, sem que seja estabelecida a garantia de regras antimajoritárias, as quais são introduzidas a fim de preservar a voz das minorias representadas no parlamento. Tais decisões políticas são tomadas, ainda, sem o controle exercido por eleições periódicas. Nesses termos, a pretensão de legitimidade das decisões judiciais, ao vincular a decisão às aspirações da sociedade, legitima o uso da força como meio de satisfazer a voz da maioria, ensejando a imposição do princípio democrático sem as garantias do constitucionalismo. Por outro lado, o uso da lei contra a voz da maioria enfatiza tais garantias em detrimento da força legitimadora da democracia.

Para Chantal Mouffe (2009), diferentemente, democracia e constitucionalismo estão em estado de conflito permanente. A tensão entre Lei e Política, constitucionalismo e democracia não pode ser bipartida entre órgãos, porquanto está presente em todos os momentos de decisão, tanto judicial quanto legislativa. Desconsiderar tal realidade significa conservar e naturalizar uma determinada distribuição de poder entre grupos e uma determinada forma de mediar a relação entre Estado e sociedade.

$\mathrm{Na}$ realidade, quando a interpretação do Direito vigente não oferece resposta concreta a um problema, a decisão depende de uma opção política e, como tal, deve ser atribuída a quem possui autoridade política para optar entre duas soluções possíveis em um caso de colisão, em respeito ao princípio da separação dos poderes, ao princípio democrático e ao próprio Estado de Direito.

\section{REFERÊNCIAS BIBLIOGRÁFICAS}

Alcântara, Michele Alencar da Cruz. Princípios da proporcionalidade, da ponderação e da concordância prática: semelhanças e distinções. Revista de Direito Privado. vol. 43. p. 72-93. São Paulo: Ed. RT, jul.-set. 2010.

AlEXY, Robert. Conceito e validade do direito. São Paulo: WMF Martins Fontes, 2009.

. El concepto y la validez del derecho. 2. ed. Barcelona: Gedisa, 1997.

Constitutional rights, balancing and rationality. Ratio Juris. vol. 16. n.

2. p. 131-140. Oxford: Blackwell Publishers, jun. 2003.

Direitos fundamentais, ponderação e racionalidade. Revista de Direito Privado. vol. 24. p. 334-344. São Paulo: Ed. RT, out. 2005b. Trad. Luís Afonso Heck. Artigo publicado originalmente na Ars Interpretandi. Yearbook of Legal Hermeneutics 7, 2002, S. 113 ff. Título original: Grundrechte, Abwägung und Rationalität.

. Teoria da argumentação jurídica: a teoria do discurso racional como teoria da fundamentação jurídica. 2. ed. São Paulo: Landy, 2005a.

Teoria dos direitos fundamentais. São Paulo: Malheiros, 2008. 
Atienza, Manuel. As razões do direito: teorias da argumentação jurídica. 3. ed. São Paulo: Landy, 2006.

Ávila, Humberto. Conteúdo, limites e intensidade dos controles de razoabilidade, de proporcionalidade e de excessividade das leis. Revista de Direito Administrativo. vol. 236. p. 369-384. Rio de Janeiro: Atlas, abr.-jun. 2004.

Teoria dos princípios: da definição à aplicação dos princípios jurídicos. 12 . ed. ampl. São Paulo: Malheiros, 2011.

Barcellos, Ana Paula de. Neoconstitucionalismo, direitos fundamentais e controle das políticas públicas. Revista de Direito Administrativo. vol. 240. p. 83-103. Rio de Janeiro: Renovar, abr.-jun. 2005.

Normatividade dos princípios e o princípio da dignidade da pessoa humana na constituição de 1988. Revista de Direito Administrativo. vol. 221. p. 159-188. Rio de Janeiro: Renovar, jul.-set. 2000.

Ponderação, racionalidade e atividade jurisdicional. Rio de Janeiro: Renovar, 2005.

Barroso, Luís Roberto; Barcellos, Ana Paula de. O começo da história: A nova interpretação constitucional e o papel dos princípios no direito brasileiro. Interesse Público. vol. 5. n. 19. p. 51-80. Sapucaia do Sul: Fórum, maio-jun. 2003.

Bernardes, Wilba Lúcia Maia; Chaves, Glenda Rose Gonçalves; Moureira, Diogo Luna (coords.). Direito público: perspectivas e atualidades. Belo Horizonte: Del Rey, 2010.

Bustamante, Thomas da Rosa de. Princípio, regras e a fórmula de ponderação de Alexy: um modelo funcional para argumentação jurídica?. Revista de Direito Constitucional e Internacional. vol. 54. p. 76-107. São Paulo: Ed. RT, jan.-mar. 2006.

. Sobre o conceito de norma e a função dos enunciados empíricos na argumentação jurídica segundo Friedrich Müller e Robert Alexy. Revista de Direito Constitucional e Internacional. vol. 43. p. 98-109. São Paulo: Ed. RT, abr.-jun. 2003.

Cattoni de Oliveira, Marcelo Andrade. Devido processo legislativo: uma justificação democrática do controle jurisdicional de constitucionalidade das leis e do processo legislativo. 2. ed. Belo Horizonte: Mandamentos, 2006.

. Direito processual constitucional. Belo Horizonte: Mandamentos, 2001.

Cezne, Andrea Nárriman. A teoria dos direitos fundamentais: uma análise comparativa das perspectivas de Ronald Dworkin e Robert Alexy. Revista de Direito Constitucional e Internacional. vol. 52. p. 51-67. São Paulo: Ed. RT, jul.-set. 2005.

Condé, Mauro Lúcio Leitão. As teias da razão: Wittgeinstein e a crise da racionalidade moderna. Belo Horizonte: Argvmentvm, 2004.

Wittgenstein: linguagem e mundo. São Paulo: Annablume, 1998. 
Dimoulis, Dimitri; Duarte, Écio Oto (coords.). Teoria do direito neoconstitucional: superação ou reconstrução do positivismo jurídico? São Paulo: Método, 2008.

; Martins, Leonardo. Teoria geral dos direitos fundamentais. 3. ed. São Paulo: Ed. RT, 2011.

Ferraz, Leonardo de Araújo. Crítica ao princípio da proporcionalidade como fundamento das decisões judiciais: abordagem à luz da teoria discursiva do direito. Dissertação de mestrado, Minas Gerais, PUC, 2007.

Galuppo, Marcelo Campos (coord.). Constituição e democracia: fundamentos. Belo Horizonte: Fórum, 2009.

Constitutional hermeneutics and pluralism. Amsterdam: Franz Steiner Verlag, 2001.

A contribuição de Esser para a reconstrução do conceito de princípios jurídicos. Revista de Direito Comparado. vol. 3. p. 227-243. Belo Horizonte: UFMG, maio 1999.

Direito e moral na Filosofia de Habermas. XV Conferência Nacional da Ordem dos Advogados do Brasil. 4 a 8 de setembro de 1994. Foz do Iguaçu.

. A epistemologia jurídica entre o positivismo e o pós-positivismo. Revista do Instituto de Hermenêutica Jurídica. n. 3. p. 195-206. Porto Alegre: Instituto de Hermenêutica Jurídica. 2005.

. Igualdade e diferença: Estado Democrático de Direito a partir do pensamento de Habermas. Belo Horizonte: Mandamentos, 2002.

Princípios jurídicos e a solução de seus conflitos: a contribuição da obra de Alexy. Revista da Faculdade Mineira de Direito. vol. 1. n. 2. p. 134-142. Belo Horizonte: Faculdade Mineira de Direito, jul. 1998.

Os princípios jurídicos no Estado Democrático de Direito: ensaio sobre o modo de sua aplicação. Boletín Jurídico de La Universidad Europea de Madrid. n. 3. Madrid: Universidad Europea de Madrid, set. 2000.

Guerra, Marcelo Lima. A proporcionalidade em sentido estrito e a "fórmula do peso" de Robert Alexy: significância e algumas implicações. Revista de Processo. vol. 141. p. 53-71. São Paulo: Ed. RT, nov. 2006.

GÜNTHER, Klaus. Uma concepção normativa de coerência para uma teoria discursiva da argumentação jurídica. Cadernos de Filosofia Alemã. n. 6. p. 85102. São Paulo: USP, 2000. Trad. Leonel Cesarino Pessôa. Artigo publicado originalmente na Rechtstheorie 20, 1989. Título original: Ein normativer Begriff der Kohärenz für eine Theorie der Juristischen Argumentation.

A normative conception of coherence for a discursive theory of legal justification. Ratio Juris. vol. 2. n. 2. Oxford: Blackwell Publishers, 1989.

Teoria da argumentação no direito e na moral: justificação e aplicação. Trad. Cláudio Molz. São Paulo: Landy, 2004. Título original: Der Sinn für Angemessenheit. Anwendungdiskurse in Moral und Recht. Frankfurt a. M.: Suhrkamp, 1988. 
Habermas, Jürgen. Faktizität und Geltung: Beiträge zur Diskurstheorie des Rechts und des demokratischen Rechtsstaats. 4. Aufl. Frankfurt a. M.: Suhkamp, 1994.

Reconciliación mediante el uso público de la razón. In: ; RAWLS, John. Debate sobre el liberalismo político. Barcelona: Paidós, 1998a.

"Razonable" versus "verdadero", o la moral de las concepciones del mundo. In: ; Rawls, John. Debate sobre el liberalismo político. Barcelona: Paidós, 1998b.

El concepto de poder de Hannah Arendt. Perfiles filosófico-políticos. Trad. Manuel Jiménez Redondo. Madrid: Taurus, 1975.

. Facticidad y validez: sobre el derecho y el Estado Democrático de Derecho en términos de teoría del discurso. Trad. Manuel Jiménez Redondo. 3. ed. Madrid: Trotta, 2001.

Heinold, Alexander. Die Prinzipientheorie bei Ronald Dworkin und Robert Alexy. Berlin: Duncker \& Humblot, 2011.

Kelsen, Hans. Teoria pura do direito. 6. ed. 3. tir. São Paulo: Martins Fontes, 1999.

Lima, Valéria das Graças Oliveira Silva e. A perspectiva principiológica do direito na jurisprudência recente do Supremo Tribunal Federal: uma crítica à ponderação de valores: um estudo de caso. Dissertação de mestrado, Minas Gerais, PUC. 2006.

LinHARES, Marcel Queiroz. O método da ponderação de interesses e a resolução de conflitos entre direitos fundamentais. Revista da Faculdade de Direito da Universidade Federal do Paraná. vol. 35. p. 219-246. Curitiba: Faculdade de Direito da Universidade Federal do Paraná, jan. 2001.

MAIA, Alexandre da. Dogmática jurídica a multiplicidade - Uma análise da teoria da argumentação jurídica de Robert Alexy. Revista do Instituto de Hermenêutica Jurídica. n. 5. p. 15-40. Porto Alegre: Instituto de Hermenêutica Jurídica, jan. 2007.

MAIA, Alexandre Campaneli Aguiar. Kelsen e a filosofia da linguagem de Wittgenstein: um estudo comparado do Tractatus logico-philosophicus e das Investigações filosóficas sobre a teoria pura do direito. Dissertação de mestrado, Minas Gerais, PUC, 2006.

Martins, Leonardo. Proporcionalidade como critério do controle de constitucionalidade:problemas de sua recepção pelo Direito e jurisdição constitucional brasileiros. Caderno de Direito. Piracicaba: Unimep (Universidade Metodista de Piracicaba), 2005.

Matos, Aníbal Magalhães da Cruz. Conflitos entre princípios constitucionais: elementos teóricos para uma compreensão adequada ao Estado Democrático de Direito. Dissertação de mestrado, Minas Gerais, PUC, 2010.

Medina, Marcelo Borges de Mattos. Esboço de uma teoria da ponderação independente da teoria dos princípios. Revista de Direito Administrativo. vol. 238. p. 43-56. Rio de Janeiro, out.-dez. 2004. 
Moreira, Luiz. Fundamentação do direito em Habermas. 3. ed. Belo Horizonte: Mandamentos, 2004.

Mouffe, Chantal. The democratic paradox. London: Verso, 2009.

. On the political. London: Routledge, 2005.

The return of the political. London: New York: Verso, 2005.

Nobre, Marcos; Rodriguez, José Rodrigo. Judicialização da política: déficits explicativos e bloqueios normativistas. Revista Novos Estudos Cebrap. n. 91. p. 5-20. São Paulo: Cebrap, nov. 2011.

Oliverra, Moisés Mileib de. O ativismo judicial e a tutela da cidadania: a postura ativista do judiciário e os riscos ao Estado Democrático de Direito. Dissertação de mestrado, Minas Gerais, PUC, 2011.

Paula, Bárbara Bruna Soares de. Construindo o direito: entre a subjetividade da justiça em Hart e Kelsen e um conceito consensual de legitimidade no pós-positivismo. Projeto de pesquisa, Minas Gerais, PUC, 2009.

Pedron, Flávio Barbosa Quinaud. Comentários sobre as interpretações de Alexy e Dworkin. Revista CEJ. vol. 9. n. 30. p. 70-80. Brasília: CEJ, jul.-set. 2005.

A ponderação de princípios pelo STF: balanço crítico. Revista CEJ. vol. 12. n. 40. p. 20-30. Brasília: CEJ, jan.-mar. 2008.

Peixinho, Manoel Messias. As teorias e os métodos de interpretação aplicados aos direitos fundamentais: doutrina e jurisprudência do STF e do STJ. Rio de Janeiro: Lumen Juris, 2010.

Schauer, Frederick. Commensurability and its constitutional consequences. Hasting Law Journal. n. 45. California: University of California, 1994.

ScHLink, Bernhard. Abwägung im Verfassungsrecht. Berlin: Duncker \& Humblot, 1976.

Freiheit durch Eingriffsabwehr. Zur Rekonstruktion der klassichen Grundrechtsfunktion. Europäische Grundrechtszeitschrift. p. 457-468, 1984.

Schwabe, Jürgen et al. Cinquenta anos de jurisprudência do Tribunal Constitucional Federal alemão. Montevideo: Konrad-Adenauer-Stiftung, 2005.

SiLva, Virgílio Afonso da (org.). Interpretação constitucional. São Paulo: Malheiros, 2005.

Direitos fundamentais: conteúdo essencial, restrições e eficácia. 2. ed. São Paulo: Malheiros, 2010.

SOARES, Guilherme. Elementos para caracterização tridimensional da dogmática jurídica: o modelo Dreier-Alexy. Sequência: estudos jurídicos e políticos. vol. 34. n. 46. p. 69-88. Florianópolis: UFSC, jul. 2003.

Souza, Débora Cardoso de. Judicialização dos direitos sociais na teoria da ponderação e no senso de adequabilidade. Dissertação de mestrado, Minas Gerais, PUC, 2010.

Souza, Vera Lúcia Ribeiro de. O labirinto e o fio de Ariadne: a proposta de Dworkin para o entendimento do direito e sua aplicação nas democracias constitucionais. Dissertação de mestrado, Minas Gerais, PUC, 2006. 
Torres, Ana Paula Repolês. Uma análise epistemológica da teoria pura do direito de Hans Kelsen. Revista CEJ. vol. 10. n. 33. p. 72-77. Brasília: CEJ, jun. 2006.

Sobre a construção intersubjetiva dos direitos positivos: a tensão interna entre facticidade e validade na teoria discursiva do Direito, de Jürgen Habermas. Revista da Faculdade Mineira de Direito. vol. 8. n. 16. p. 9-32. Belo Horizonte: Faculdade Mineira de Direito, 2. ${ }^{\circ}$ sem. 2005.

TSAKYrakis, Stavros. Proportionality: an assault on human rights?. Jean Monnet Working Paper. n. 9-8, 2008.

Wittgenstein, Ludwig. Investigações filosóficas. 2. ed. Trad. José Carlos Bruni. São Paulo: Ed. Abril Cultural, 1979.

Philosophical investigations. Oxford: Oxford, 1958.

\section{Pesquisas do Editorial}

\section{Veja também Doutrina}

- Aportes de teoria constitucional: uma abordagem sobre constituição, democracia e jurisdição constitucional, de Heloísa da Silva Krol - RDCl 65/99;

- Jurisdição e aplicação do direito em Jürgen Habermas, de Rafael Lazzarotto Simioni RePro 154/314; e

- Princípios na relação entre direito e moral algumas notas sobre o debate Habermas-Alexy, de Roberto José Ludwig - RT 915/183. 